Energy Research \&

Development Administration

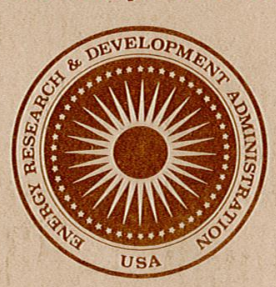

LBL-6817 C. 2

UC-95c

TID 4500-R65

\title{
A Water Conservation Scenario for the Residential and Industrial Sectors in California: Potential Savings of Water and Related Energy
}

Peter Benenson

Energy Analysis Program August 1977

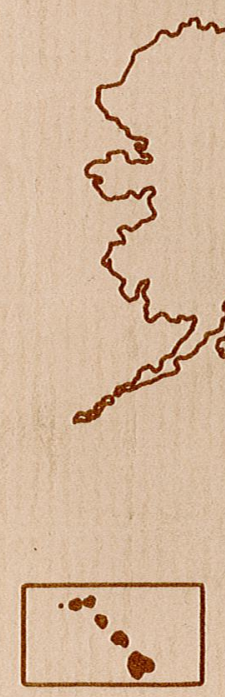

\section{TWO-WEEK LOAN COPY}

This is a Library Circulating Copy which may be borrowed for two weeks. For a personal retention copy, call Tech. Info. Division, Ext. 5716 
A WATER CONSERVATION SCENARIO FOR THE RESIDENTIAL

AND INDUSTRIAL SECTORS IN CALIFORNIA:

POTENTIAL SAVINGS OF WATER AND RELATED ENERGY

Peter Benenson

August 1977

\author{
Energy Analysis Program \\ Energy \& Environment Division \\ Lawrence Berkeley Laboratory \\ Berkeley, California 94720
}


I

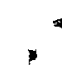

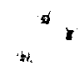

,

".

"

$\because \ldots$ 
CONTENTS

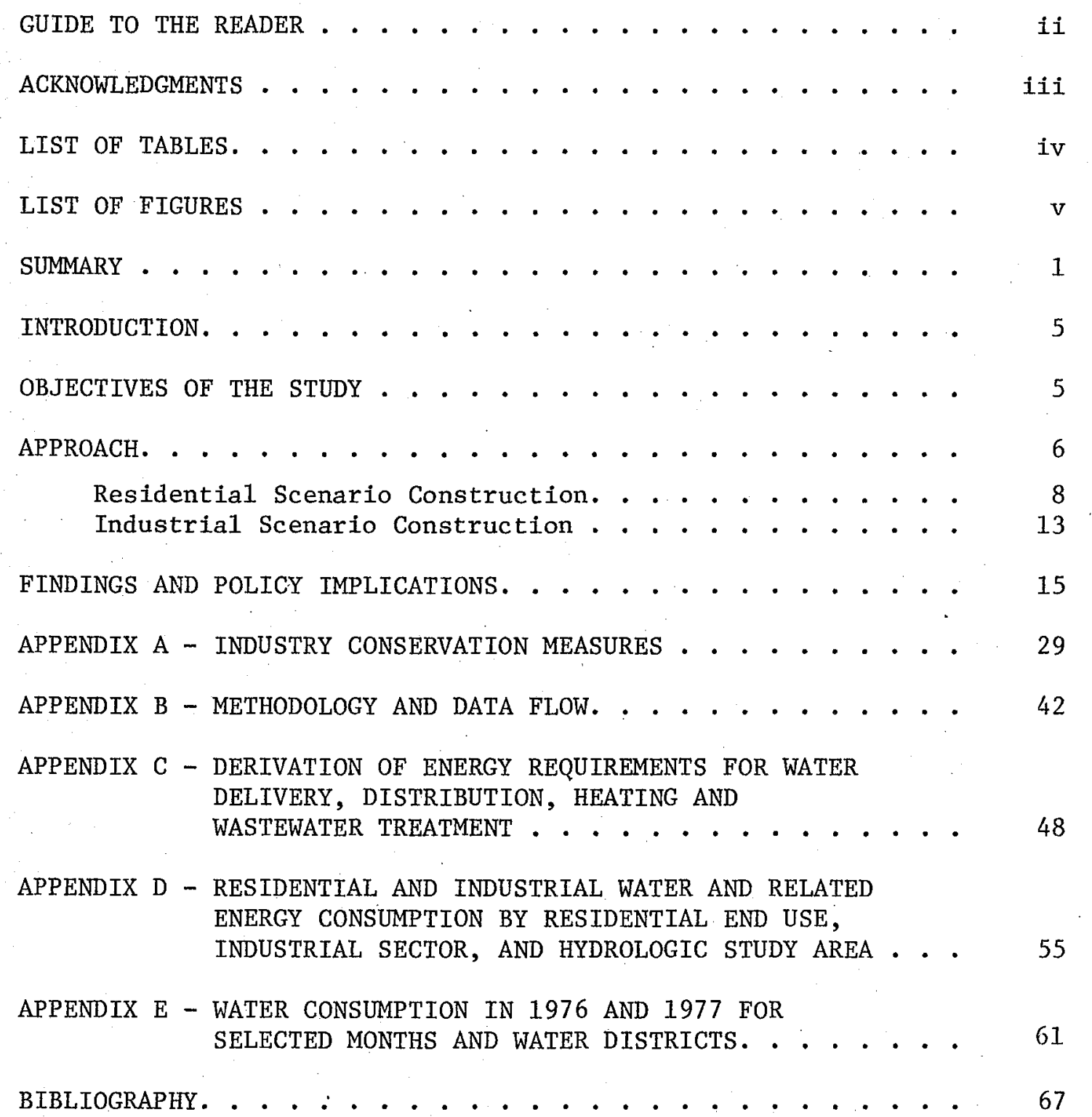


c

$+$

.

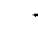

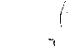

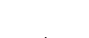

.

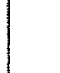


GUIDE TO THE READER

This study is written in three levels of detail: the summary, the main report, and the appendices. The summary highlights what was accomplished and presents the major results and policy implications. It is designed to provide an overview in a fifteen minute reading. The main body of the report contains the major components of the study, but the detailed data and calculations that may not interest every reader have been extracted. The main report includes the study scope placed in the context of the total California water situation, the study objectives, a description of the approach, a detailed report of the findings, and a discussion of the policy implications. The most detailed material is presented in the appendices. These are designed only for the reader who wishes either to use the data collected or to see the detailed derivations of the estimates. 
$\cdots$ 
ACKNOWLEDGMENTS

Several people contributed to the research for this study. Lauran Vincent compiled the industry conservation measures and most of the data for the industrial sector. Betsy Krieg estimated the energy requirements for surface water deliveries, groundwater pumping, and water distribution. Barbara Greene researched the interior and exterior residential water use estimates and, with Robert Clear, computed the energy requirements for water heating. Henry Ruderman wrote the computer programs for the water conservation scenarios. Yvonne Howe11 edited the text and made helpful suggestions to improve the clarity and continuity of the presentation.

I am grateful for review and comment from Eugene Eno, Trancuilo Canton, John Harte, Edward Kahn, Laura Nader, Ronald Ritschard, Edwin Roberts, Glenn Sawyer, Lee Schipper, Stephen Schneider, William Siri, Zach Willey, Fred Winyard, and Ronald West. 
LIST OF TABLES

Table No.

Table Title

Page

1 .

Residential Interior Water Use

Energy Requirements for Water Use.

10

3

Residential Water Conservation by End Use

12

4.

Water Conservation Measures Applicable to Industry

14

Water and Associated Energy Consumption by

Hydrologic Study Area

Residential Water and Associated Energy

Consumption by End Use

Industrial Water and Associated Energy Use by Sector

Summary of Estimated Change in Municipal Water Consumption: 1976 to 1977

Preliminary Results from the Water Conservation Program at the Lawrence Berkeley Laboratory the San Francisco and South Coastal Hydrologic Study Areas

Wastewater Treatment Facilities: Assumed Plant Size and Level of Treatment 


\section{LIST OF FIGURES}

Figure No.

Water Storage and Conveyance Facilities 


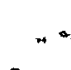

$+$

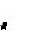

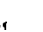

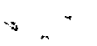


SUMMARY

A residential and industrial water conservation scenario for California has been constructed in which water consumption has been disaggregated by residential end-use, industrial sector, and hydrologic study area. The energy use associated with this water use was estimated for surface and groundwater delivery, distribution, heating, and wastewater treatment. For each end-use and sector, water conservation measures have been delineated and their potential savings in terms of both water and attendant energy use have been estimated. This material has been combined to estimate the total water and energy savings potential by end-use, sector, and HSA. This potential is then compared with the reported water savings to date, and finally, some conclusions and policy implications are drawn from the results. The general findings are discussed first, followed by a listing of the more important detailed results.

There are several important links between water and energy. In California, water is a major source of energy supply: in 1975, 25\% of total electric energy was supplied by hydroelectric power. Water is also needed for power plant cooling and fossil fuel extraction and refining. Energy is required to extract, convey, purify, and heat water prior to use, and to treat wastewater. Thus water conservation results in water and energy savings. The estimates from this study indicate that approximately 1.8 million acre feet of water, 2.6 billion $\mathrm{kWh}$ of electricity, and 0.5 billion therms of natural gas could be saved this year from implementing the water conservation measures presented in Tables 3 and 4 . This constitutes $38 \%$ of the estimated residential and industrial water use (approximately $5 \%$ of Statewide water use), $2 \%$ of Statewide electricity consumption, and $3 \%$ of Statewide natural gas consumption. The electricity savings would lead to a decreased consumption of nonrenewable fuels and to decreased pollution emissions. 
The estimated savings potential is thought to be conservative because several water districts and industries have already reported far greater savings. However, the lack of data for the industrial sector prevented any further estimates. A comparison of the estimated water savings potential with the savings actually reported shows that while the estimated potential is attainable, and in some cases has been exceeded, overall only $1 / 3$ of the conservation potential derived in this study has been reached. Moreover, the actual gap is probably even greater due to the conservative nature of our estimates.

This significant conservation potential can be regarded as an alternative to constructing water supply systems for protection against water scarcity. For example, in the San Francisco HSA the estimated annual water savings potential of 410,000 acre feet exceeds the estimated deliveries from the major proposed water supply projects there. In the South Coastal HSA the estimated potential savings of 820,000 acre feet annually is more than twice as large as the current short run overdraft in the Owens Valley. Statewide, the estimated potential savings is approximately $40 \%$ of urban fresh water use in 1972.

Therefore, for optimal water supply planning, the pros and cons of both dams and water conservation should be considered. Dams regulate the water supply and provide flood control, hydroelectric power, and lakes for recreation. But they are costly, employ few people relative to other projects of comparable costs, and have many negative environmental impacts (e.g., they destroy natural habitats and accelerate eutrophication). Water conservation eases the water scarcity and has none of the environmental impacts associated with dams. Many measures can be implemented cheaply and quickly.

One of the main difficulties to relying on water conservation is the potential for sustained consumer resistance to behavioral change. The residential and industrial consumer directly perceives the inconvenience of water conservation, but not of dam construction. In the latter case, local residents absorb most of the inconvenience and the financial cost is borne by the taxpayers. Generally, the costs of these two alternatives are not equally apparent; this hinders the 
process of evaluation of the alternatives, and hence of rational water supply planning.

The objection of potential consumer resistance to behavioral change applies mainly to conservation measures that require continuous attention to the resource in question. But large savings are possible from conservation measures that require a one-time installment of a technological device. As savings accrue from these types of measures, the likelihood of reaching full conservation potential will be easier to assess because we will have more experience with conservation. The possibilities include such diverse outcomes as rejection of any effort to conserve and complete integration of water conserving behavior into daily routines.

Present1y, although conservation cannot be relied upon with certainty as an option equivalent to its full potential for protection against water scarcity, it cannot be ignored as often has been the case in the past. Although surplus capacity for water supply has large economic and social value, to plan for water supply based on historic water consumption patterns would result in suboptimal water supply planning. Given the advantages and disadvantages of dam construction and water conservation, a rational water supply planning process requires reassessment of plans for construction of additional water supply systems that were made prior to the availability of recent evidence on water conservation potential.

The more detailed results upon which these general conclusions are based are summarized below:

- Overall residential water consumption can be reduced by $44 \%$ of average use by implementing the measures in Table 3 . Electricity and natural gas consumption associated with this water use could be reduced by about the same percentage.

- Exterior water use, toilet flushing, and bathing are the largest residential water uses. Conservation efforts applied to these end uses will result in the largest reductions in residential water consumption.

- The highest per capita electricity consumption associated with water use occurs in the South Coastal HSA where $57 \%$ of the State's population resides. 
- Of the four energy components considered, energy for water heating dominates the energy uses associated with water consumption. Potential natural gas savings are greater than potential electricity savings because gas hot water heaters are more prevalent than electric water heaters in California.

- Bathing and laundry rank first and second for energy consumption among residential water uses because of the high volume of hot water used.

- According1y, water conservation measures that reduce water for bathing and laundry, and al1 measures that reduce water consumption in the South Coastal and San Francisco HSAs (where the energy required for water delivery is relatively high) would have the largest impacts in water-related energy savings.

- Industrial water consumption and the associated energy requirements for water delivery and distribution can be reduced by at least $19 \%$ and $23 \%$, respectively. This is thought to be a conservative estimate.

- The conservation measures that can be applied most immediately are housekeeping measures, some closed cycle cooling water reductions, and reuse of process water where extensive retrofitting of equipment is not required.

- The centers of industrial water consumption are the South Coastal and San Francisco HSAs. Water-related energy use also is highest here because of the energy requirements for delivery and distribution. So relatively large and immediate water and energy savings can be made by implementing the above mentioned water conservation measures in these areas.

- So far the largest savings potentials reported are in the paper and petroleum sectors. Food processing should be given special attention because it is the largest industrial water user. 


\section{INTRODUCTION}

This study of the use and conservation of water and water-related energy was made in conjunction with a broader examination of the effects of the drought on energy consumption and peak electrical generating capacity in California [17]. The initial work focused on the water, energy, and power situation during the summer of 1977.

The link between drought, energy consumption, and peak electrical capacity involves both water and energy supply demand. Water is a major source of energy supply in California; in 1975, 25\% of total electrical energy supply for the State was generated by hydroelectric power. Water is also needed for power plant cooling.

On the demand side, energy is required to extract, convey, purify, and heat fresh water, as well as to treat waste water. There is also a direct relationship between water demand and peak power demand since some water use always occurs during periods of peak electrical demand. Moreover, during a drought, the energy requirements for groundwater pumping increase, because the supply of surface water is reduced and because the water table is lower. In agriculture, this increase in the energy needed for pumping water may be reduced either by a decrease in the acreage planted or by water conservation; and in urban areas, by water conservation.

\section{OBJECTIVES OF THE STUDY}

The total California water demand in 1972 (a typical water year) was apportioned as follows:

$$
\begin{array}{ll}
\text { residential sector } & -9 \% \\
\text { industrial sector } & -2 \% \text { (excluding brackish water use) } \\
\text { agricultural sector }-85 \%[6, p .89 ; 8, p .14]^{*}
\end{array}
$$

The annual electricity consumption associated with water use in the residential and industrial sectors is about 6.5 billion $\mathrm{kWh}$; for agriculture, it is about 4 billion $\mathrm{kWh}$. These energy requirements for

* Numbers in square brackets [ ] refer to items in the bibliography. 
water use are comparatively small when viewed in the context of the total electricity consumption in California - 4\% and $3 \%$ of the total, respectively. However, if these percentages are significantly altered, they could impact both the electrical capacity reserve margins and fuel use required for electricity generation. The impact of changes in water consumption is relatively larger than for electricity consumption, owing to the larger percentages of total water use attributable to these sectors.

Accordingly, the objectives in this study are to determine the impact of current and potential water conservation efforts for reducing both water consumption and the attendant energy and peak power demand, to pinpoint the water conservation strategies that are likely to have the largest impacts on energy and water demand, and to highlight some of the complementarities between water and energy use.

\section{APPROACH}

To accomplish these objectives, it is first necessary to determine present water use in major geographic regions of California by residential end-use and by industrial sector, and to trace the energy use associated with this water, from its extraction and delivery to wastewater treatment.

In developing the scenarios for this study, the data have been disaggregated by residential end-use, industrial sector, and hydrologic study area (HSA). The sector and end-use disaggregations are used to determine the potential for energy and water savings from specific water conservation measures. The geographic disaggregation helps capture the variability across the state in energy requirements for water delivery. These energy requirements vary because, in general, the major sources of water in the State are not located near the major points of use. The map of water storage and conveyance facilities (Fig. 1) clearly illustrates this situation. Water is conveyed from northern California to southern California, from the Sierra to the Central Valley and San Francisco, from the Owens Valley to Los Angeles, and from the 


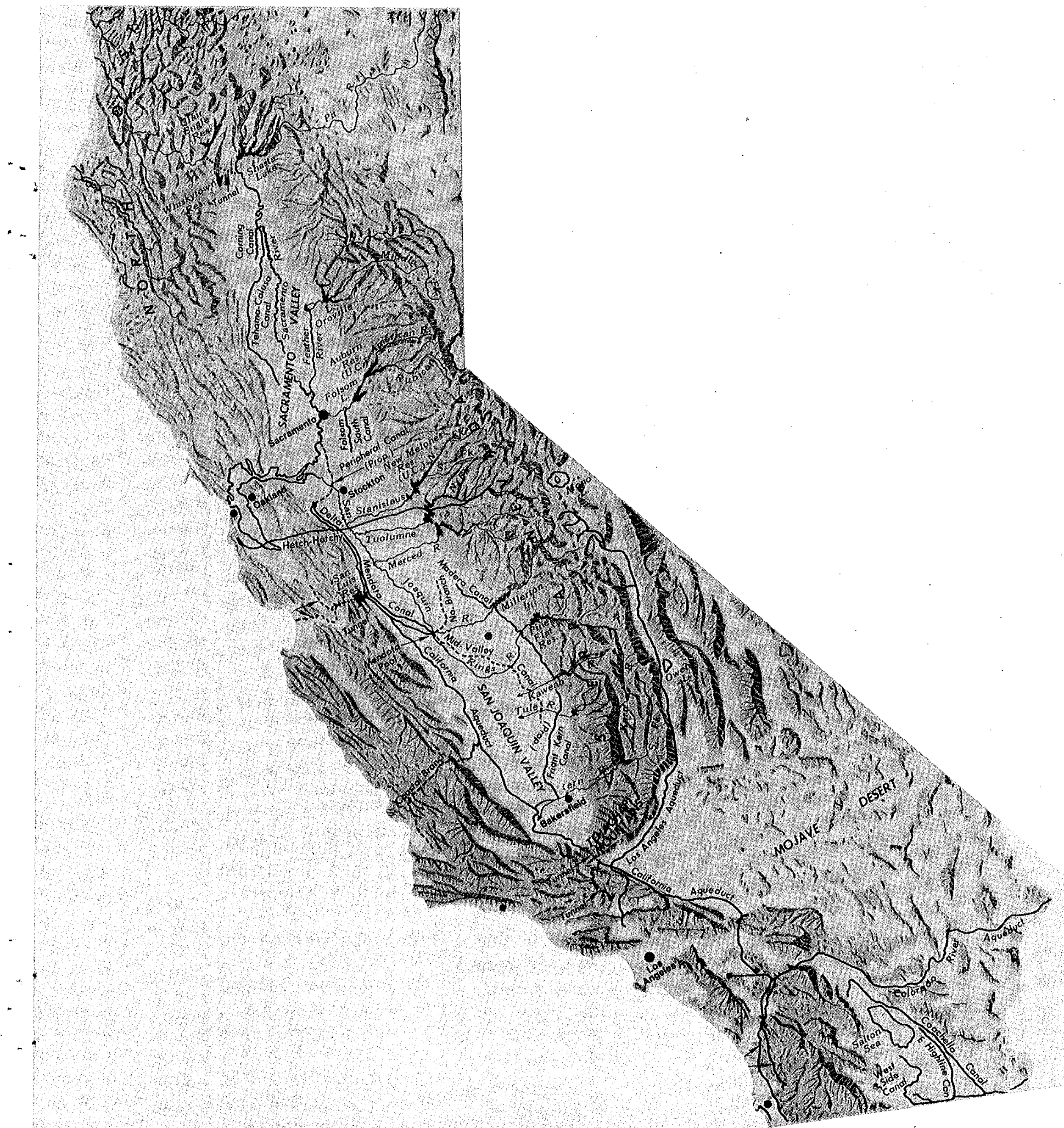

Figure 1

Water Storage and Conveyance Facilities in California

Source: [18] 
Colorado River to San Diego and Los Angeles, Also, there are regional differences in the energy required for groundwater pumping. The HSA boundaries are shown in Fig. 2 .

Once the water and associated energy use are determined, the next steps are to find how water can be saved in each end-use and industrial sector, and to estimate how much can be saved. Finally, this information is combined to construct a scenario of water and attendant energy use before and after water conservation. The details of this approach are described separately for each sector in the text below and in Appendix $B$.

\section{Residential Scenario Construction}

The scenario for the residential sector begins with an estimate of interior and exterior water use; interior use is broken down into detailed end-uses such as toilet flushing, bathing, etc. (Table 1).

Table 1

RESIDENTIAL INTERIOR WATER USE

\begin{tabular}{|c|c|c|c|}
\hline End Use & $\underset{{ }^{\circ}}{\text { Temperature }}$ & $\begin{array}{l}\text { Gallons/. } \\
\text { Person } / \\
\text { Year }\end{array}$ & Comments \\
\hline Toilet & 60 & 9125 & $\begin{array}{l}\text { 5-gallon toilet flushed } \\
5 \text { times per day }\end{array}$ \\
\hline Bathing & 105 & 7300 & $\begin{array}{l}5 \text { showers per person per } \\
\text { week, } 5 \text { gallons per minute, } \\
5-6 \text { minutes per shower }\end{array}$ \\
\hline Laundry & 130 & 3194 & $\begin{array}{l}62 \text { gallons per person per } \\
\text { week }\end{array}$ \\
\hline Dishwashing & $105-140$ & 1369 & \\
\hline Cooking, Drinking & 60 & 1095 & \\
\hline Bathroom Sink & 105 & 730 & \\
\hline Utility Sink & 105 & 456 & \\
\hline TOTAL & & 23,269 & \\
\hline
\end{tabular}

Sources: $[28,30,33,34]$ 


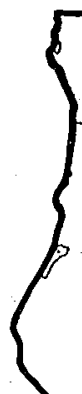

HYDROLOGIC STUDY AREAS

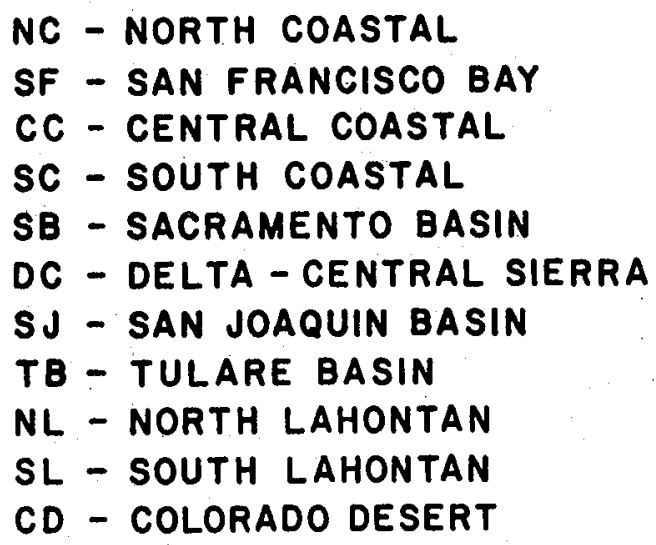

SF - SAN FRANCISCO BAY

CC - CENTRAL COASTAL

SC - SOUTH COASTAL

SB - SACRAMENTO BASIN

DC - DELTA - CENTRAL SIERRA

SJ - SAN JOAQUIN BASIN

TB - TULARE BASIN

NL - NORTH LAHONTAN

CD - COLORADO DESERT

FIGURE 2

XBL 776-8970A

HydRologic Study AREA BOUNDARIES 
TABLE 3

RESIDENTIAL WATER CONSERVATION BY END USE

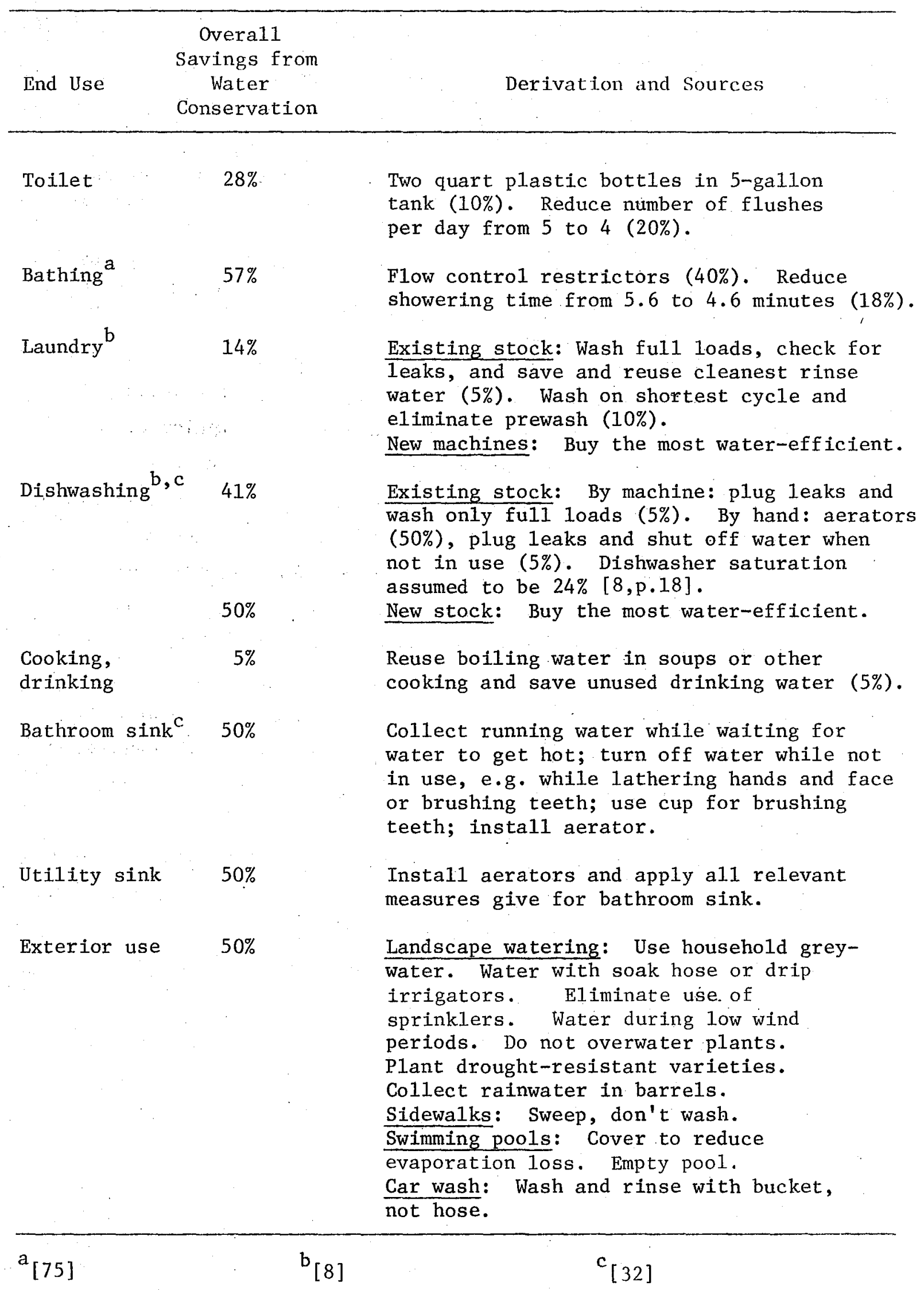


Industrial Scenario Construction

The industrial sector scenario begins with the selection of the largest industrial water users. In decreasing order of fresh water use in 1970 these are:

- Food and kindred products

- Paper and allied products

- Petroleum and coal products

- Chemical and allied products

- Lumber and wood products

- Stone, clay, and glass products

- Primary metals

These users account for $86 \%$ of the industrial water consumption in California [40, Table 6]. The rest of the industries are aggregated into a category called "other industries."

For each industrial category, estimates are made of the water use, both fresh and brackish, as we11 as the energy needed for water delivery in each HSA and for delivery plus distribution in the San Francisco and South Coasta1 HSAs. After energy and water use per employee are calculated, total water and associated energy use for 1977 are estimated from an extrapolation of employment in each industry [41,62].

Then the water conservation potential in each industrial sector is estimated. The water conservation measures for the industrial sectors are broken down by industry and by three generic categories - housekeeping, cooling, and effluent reduction for reuse. These categories, defined in Table 4 and Appendix A, correspond to the three ways that industry can conserve water: for the water that is now being wasted, the housekeeping measures apply; where the water temperature is being increased, it can be cooled for reuse; where its quality is decreased, it can be used in processes that tolerate lower quality water or it can be purified and reused. Table 4 summarizes the applicability of these water conserving measures to the seven largest water-consuming industries and also shows the estimated potential for water conservation in each industry; the industry-specific conservation measures from which this generic compilation was made are presented in Appendix A. 
TABLE 4

WATER CONSERVATION MEASURES APPLICABLE TO INDUSTRY ${ }^{a}$

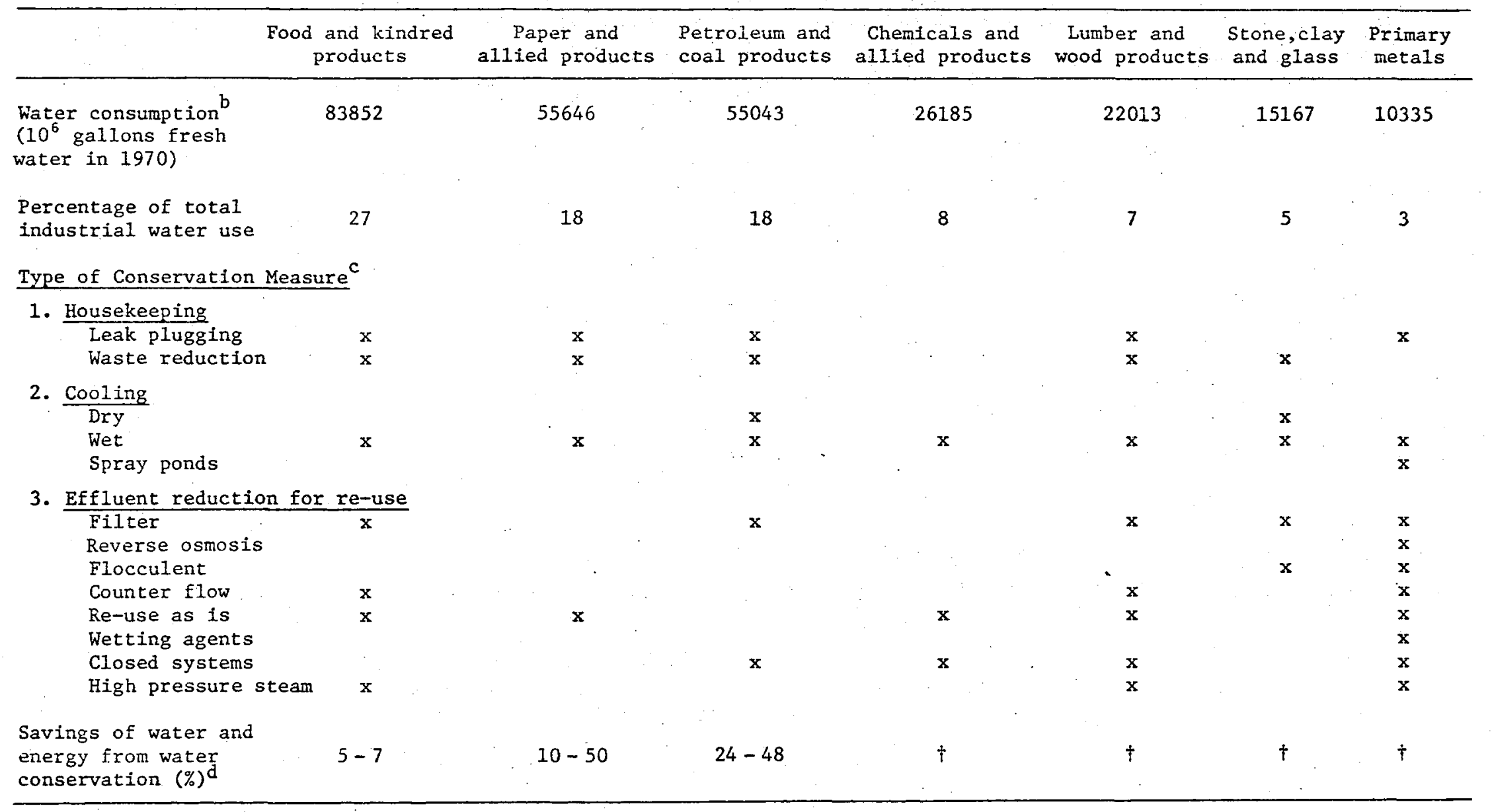

a $x$ denotes applicabllity as indicated in the source document listed in $c$ below.

b $[40]$

c [45]

d $[47]$

$\dagger$ Five percent water and energy savings from water conservation is assumed in these industries. 
Because the conditions in each firm within an industry vary greatly with respect to the age and quality of capital stock, water conservation measures previously implemented, geographical locations, and quality of water available, a range rather than a point estimate was obtained for the savings potential due to water conservation. For some industries, data on potential savings were unavailable. In these cases, it was assumed that a minimum of $5 \%$ savings of water and associated energy is obtainable simply by improving housekeeping practices, reusing process water to a limited extent, and reducing blowdown and evaporation losses in cooling towers through regular tower maintenance, installation of extra filters, increasing concentration in the cooling water where conditions permit, and installing automatic control of cooling water temperatures. The potential savings in cooling towers alone can be substantia1, ranging between $10 \%$ and $50 \%$ of the cooling water intake normally used. Presently, these savings are not quantified because of the lack of data on water used for closed-cycle cooling in each industry. For these reasons the savings estimates are conservative.

Once the savings potential is estimated, calculations are made (as for the residential sector) of the water and associated energy consumption expected this year without water conservation, and the consumption that would result with full conservation implementation.

\section{FINDINGS AND POLICY IMPLICATIONS}

The results of the above calculations yield estimates of the residential and industrial water and associated energy consumption, by end-use and sector, respectively, and by HSA before and after water conservation. These detailed estimates are presented in Appendix $D$. The summary totals, aggregated over residential end-uses and industrial sectors or across HSAs, are given in Tables 5-7.

The total estimated consumption for 1977 without water conservation is 1568 billion gallons of water, 6.5 billion $\mathrm{kWh}$ of electricity, and 1.4 billion therms of natural gas. This represents approximately $13 \%$, $4 \%$, and $8 \%$, respectively, of the Statewide consumption of these resources (including brackish water use in industry). 
TABLE 5

WATER AND ASSOCIATED ENERGY CONSUMPTION BY HYDROLOGIC STUDY AREA

\begin{tabular}{|c|c|c|c|c|c|c|c|c|c|c|}
\hline \multirow{2}{*}{$\begin{array}{l}\text { Hydrologic } \\
\text { study area } \\
\text { (HSA) }\end{array}$} & \multicolumn{3}{|c|}{ Residential } & \multicolumn{2}{|c|}{ Industria1 } & \multicolumn{3}{|c|}{ Residentia1 } & \multicolumn{2}{|c|}{ Industrial } \\
\hline & $\begin{array}{c}\text { Water } \\
10^{9} \text { gal }\end{array}$ & $\begin{array}{c}\text { Electricity } \\
10^{6} \mathrm{kWh}\end{array}$ & $\begin{array}{c}\text { Natural } \\
\text { gas } \\
10^{6} \text { therms }\end{array}$ & $\begin{array}{c}\text { Water } \\
10^{9} \mathrm{ga} 1\end{array}$ & $\begin{array}{c}\text { Electrlcity } \\
10^{6} \mathrm{kWh}\end{array}$ & $\begin{array}{c}\text { Water } \\
10^{9} \mathrm{gal}\end{array}$ & $\begin{array}{c}\text { Electricity } \\
10^{6} \mathrm{kWh}\end{array}$ & $\begin{array}{c}\text { Natural } \\
\text { gas } \\
10^{6} \text { therms }\end{array}$ & $\begin{array}{c}\text { Water } \\
10^{9} \mathrm{ga} 1\end{array}$ & $\begin{array}{c}\text { Electricity } \\
10^{6} \mathrm{kWh}\end{array}$ \\
\hline 1. North Coastal & 11 & 63 & 20 & 30 & 7 & 6 & 38 & 13 & 19 & 4 \\
\hline 2. San Francisco Bay & 219 & 1216 & 321 & 140 & 138 & 125 & 716 & 191 & 99 & 104 \\
\hline 3. Central Coastal & 44 & 211 & 61 & 18 & 4 & 25 & 126 & 36 & 14 & 3 \\
\hline 4. South Coastal & 553 & 3648 & 786 & 132 & 242 & 315 & 2148 & 468 & 103 & 198 \\
\hline 5. Sacramento Basin & 105 & 284 & 84 & 30 & 7 & 57 & 169 & 50 & 25 & 6 \\
\hline 6. De1ta-Central Sierra & 31 & 109 & 33 & 46 & 15 & 17 & 64 & 20 & 35 & 13 \\
\hline 7. San Joaquin Basin & 42 & 114 & 32 & 24 & 15 & 22 & 67 & 19 & 22 & 14 \\
\hline 8. Tulare Basin & 78 & 234 & 55 & 19 & 20 & 42 & 134 & 33 & 18 & 19 \\
\hline 9. North Lahontan & 3 & 10 & 3 & 2 & 1 & 2 & 6 & 2 & 2 & 1 \\
\hline 10. South Lahontan & 20 & 85 & 21 & 8 & 7 & 11 & 50 & 13 & 7 & 7 \\
\hline 11. Colorado Desert & 13 & 43 & 11 & 1 & 1 & 7 & 25 & 7 & 1 & 1 \\
\hline 12. Total Cal1fornia & 1119 & 6017 & 1427 & 449 & 457 & 629 & 3542 & 850 & 345 & 368 \\
\hline
\end{tabular}


TABLE 6

RESIDENTIAL WATER AND ASSOCIATED ENERGY CONSUMPTION BY END USE

\begin{tabular}{|c|c|c|c|c|c|c|c|}
\hline \multirow[b]{2}{*}{ End Use } & \multicolumn{3}{|c|}{ Without Water Conservation } & \multicolumn{3}{|c|}{ With $100 \%$ Water $\mathrm{Cor}$} & n Implementation \\
\hline & $\begin{array}{l}\text { Water } \\
10^{9} \text { gal }\end{array}$ & $\begin{array}{c}\text { Electricity } \\
10^{6} \mathrm{kWh}\end{array}$ & $\begin{array}{l}\text { Natura } 1 \text { Gas } \\
10^{6} \text { therms }\end{array}$ & & $\begin{array}{l}\text { Water } \\
10^{9} \mathrm{gal}\end{array}$ & $\begin{array}{c}\text { Electricity } \\
10^{6} \mathrm{kWh}\end{array}$ & $\begin{array}{l}\text { Natural Gas } \\
10^{6} \text { therms }\end{array}$ \\
\hline Tollet & 194 & 482 & 0 & & 140 & 347 & 0 \\
\hline Bathing & 155 & 2271. & 699 & & 67 & 977. & . 301 \\
\hline Laundry & 68 & 1451 & 481 & & 58 & 1248 & 414 \\
\hline Dishwashing & 29 & 424 & 132 & & 17 & 250 & 78 \\
\hline Cooking and drinking & 23 & 59 & 0 & & 22 & 56 & 0 \\
\hline Bathroom sink & 16 & 228 & 70 & & 8 & 114 & 35 \\
\hline Utility sink & 10 & 141 & 45 & & 5 . & 71 & 22 \\
\hline Exterior & 624 & 960 & 0 & & 312 & 480 & 0 \\
\hline TOTAL & 1119 & 6017 & 1427 & & 629 & 3542 & 850 \\
\hline
\end{tabular}

TABLE 7

INDUSTRIAL WATER AND ASSOCTATED ENERGY USE BY SECTOR

\begin{tabular}{|c|c|c|c|c|}
\hline \multirow[b]{2}{*}{ Sector } & \multicolumn{2}{|c|}{ Without Water Conservation } & \multicolumn{2}{|c|}{$\begin{array}{l}\text { With } 100 \% \text { Water } \\
\text { Conservation Implementation }\end{array}$} \\
\hline & $\begin{array}{l}\text { Water } \\
10^{9} \mathrm{gal}\end{array}$ & $\begin{array}{l}\text { Electricity } \\
10^{6} \mathrm{kWh}\end{array}$ & $\begin{array}{l}\text { Water } \\
10^{9} \mathrm{gal}\end{array}$ & $\begin{array}{l}\text { Blectricity } \\
10^{6} \mathrm{kWh}\end{array}$ \\
\hline Food and kindred products & 115 & 124 & .107 & 115 \\
\hline Lumber and wood products & 30 & 14 & 28 & 13 \\
\hline Paper and allied products & 84 & 61 & 42 & 31 \\
\hline Chemicals and allied products & 53 & 43 & 50 & 41 \\
\hline Petroleum and coal products & 98 & 83 & 51 & 43 \\
\hline Stone, clay and glass products & 16 & 26 & 15 & 25 \\
\hline Primary metals & 10 & 19 & 9 & 18 \\
\hline Other Industries & 44 & 87 & 41 & 83 \\
\hline TOTAL & 449 & 457 & 345 & 368 \\
\hline
\end{tabular}


A comparison of water consumption during the first four months of 1977 in major urban areas with infornation for the same time period in 1976 yields an estimate of water conservation that is presently being implemented [55]. The Statewide reduction is 13\%; application of this figure to the 1977 estimates yields a savings of 204 billion gallons of water, 0.9 billion $\mathrm{kWh}$ of electricity, and 0.2 billion therms of natural gas $(2 \%, 0.6 \%$, and $1 \%$, respectively, of statewide resource consumption).

If the water conservation measures listed in Tables 3 and 4 were fully implemented, water consumption would be reduced by $38 \%$ with concomitant energy savings of $40 \%$. The energy use reductions imply water use reductions in accordance with the distribution of conservation measures given in Tables 3 and 4. This is one of many possible distributions.' Consumers may place a different emphasis on particular measures e.g., greater cutbacks of exterior use and less of interior use. Hot water use may or may not be among the reductions emphasized. The estimated savings are 1.8 million acre feet of water, 2.6 billion $\mathrm{kWh}$ of electricity, and 0.5 billion therms of natural gas. This amounts to $2 \%$ of the State's total electricity use, $5 \%$ of its water use, and $3 \%$ of its natural gas use. These figures are within the range of savings estimated by the Department of Water Resources [8]. How attainable are these savings? To answer this, the estimated conservation potential can be compared with three sets of water consumption data presently available:

1. A survey conducted by LBL of major municipal water agencies throughout the State. The data pertain to water consumption for selected months of 1976 and 1977 as available.

2. Four-month cumulative totals for water consumption in 1976 and 1977 in selected metropolitan water agencies throughout the State [55].

3. A record of the water consumption at the Lawrence Berkeley Laboratory in 1976 and 1977, which includes residential, commercial, and industrial type uses.

A summary by HSA of the first two sets of data is presented in Table 8; the data for the water districts from which these summary statistics are derived are included in Appendix E. These figures show 
Table 8

SUMMARY OF ESTIMATED CHANGE IN MUNICIPAL WATER CONSUMPTION: 1976 TO 1977

\begin{tabular}{|c|c|c|}
\hline$\underline{\mathrm{HSA}}$ & $\begin{array}{r}\frac{\text { Percenta }}{\text { January }- \text { May* }} \\
\text { Cumulative Tota1 }\end{array}$ & $\begin{array}{l}\text { Change } \\
\frac{\text { Selected }}{\text { Months }}\end{array}$ \\
\hline North Coastal & -18 & NA \\
\hline San Francisco Bay & -25 & -40 \\
\hline Central Coastal & -19 & -20 \\
\hline South Coastal & -3 & -2 \\
\hline Sacramento Basin & -0.6 & -18 \\
\hline Delta-Central Sierra & -18 & -17 \\
\hline San Joaquin Basin & -5 & -7 \\
\hline Tulare Basin & -11 & +7 \\
\hline North Lahontan & NA & NA \\
\hline South Lahontan & $\mathrm{NA}$ & NA \\
\hline Colorado Desert & NA & NA \\
\hline
\end{tabular}

Source $*[55]$

$+[$ LBL Survey $]$.

NA [Not available].

that in a few areas of northern California the estimated savings potential has been reached and in some cases surpassed. The latter cases occur, for example, in the Marin Municipal Water District and the East Bay Municipal Utility District, where savings of more than $50 \%$ of 1976 consumption have been achieved. Statewide, however, present water savings are far below the potential estimated, as the reported water consumption in the South Coastal and Tulare Basin HSA's indicate. 
The 1977 water consumption at the Lawrence Berkeley Laboratory is $50 \%$ of what it was in 1976 (Table 9). Significant inroads were made in end-uses that span most sectors of the economy. Water use for toilets and sinks has been reduced by $27 \%$, for cooling tower blowdown by $87 \%$, for photographic processing by $73 \%$, and for landscape irrigation by $87 \%$.

The reported consumption of the Marin and East Bay water districts and the experience at LBL point to the feasibility of the water conservation potential estimated above (38\% with full conservation implementation). But the Statewide savings indicate that the level of conservation currently being achieved is only about one-third of this potential. Moreover, this potential is believed to be conservative, primarily because the data for the industrial sector are inadequate to assess the full conservation potential there, and because greater savings than those estimated in this study have already been reported by the water districts mentioned above and by several industries (Table 10). Therefore, although the water saving potential is quite large and attainable, the gap between actual and potential water savings is even greater than the results of this study indicate.

This finding bears on the policy decisions for water supply planning, as it means that water conservation can be considered an alternative to construction of additional water supply systems for protection against future water scarcity. In the San Francisco HSA, for example, the estimated potential savings are 410,000 acre-feet per year. This exceeds the estimated deliveries from the major proposed urban water supply projects in this area (San Felipe - 143,000 acre-feet per year, the EBMUD portion of the Auburn Dam deliveries - 150,000 acrefeet per year, and the fourth San Joaquin pipeline to convey Tuolomne River water, 110,000 acre-feet per year). In the South Coasta1 HSA the potential savings are 820,000 acre feet per year, which is more than twice the present rate of short-run overdraft from the Owens Valley. Statewide, the estimated savings potential through conservation is 1. 8 million acre-feet, roughly $40 \%$ of total urban fresh water use in 1972 . 
Table 9

PRELIMINARY RESULTS FROM THE WATER CONSERVATION PROGRAM AT THE LAWRENCE BERKELEY LABORATORY† (ALL UNITS IN GALLONS PER MINUTE UNLESS OTHERWISE NOTED)

\begin{tabular}{|c|c|c|}
\hline Use & $\frac{\text { Pre-conservation }}{\frac{\text { Summer Rate }}{1976}}$ & $\frac{\text { Use to Date }}{\text { After Water }}$ \\
\hline Toilets, Sinks & 30 & 22 \\
\hline Cooling Towers & & \\
\hline Blowdown & 15 & 2 \\
\hline Evaporation & 80 & 68 \\
\hline Photographic Processes & 15 & 4 \\
\hline Dilution and Cleaning & 10 & 7 \\
\hline Once through Cooling & 65 & 15 \\
\hline Roof Soaker Cooling & 10 & 0 \\
\hline Landscape Irrigation & $15 *$ & $2 *$ \\
\hline TOTAL & 240 & 120 \\
\hline
\end{tabular}


Table 10

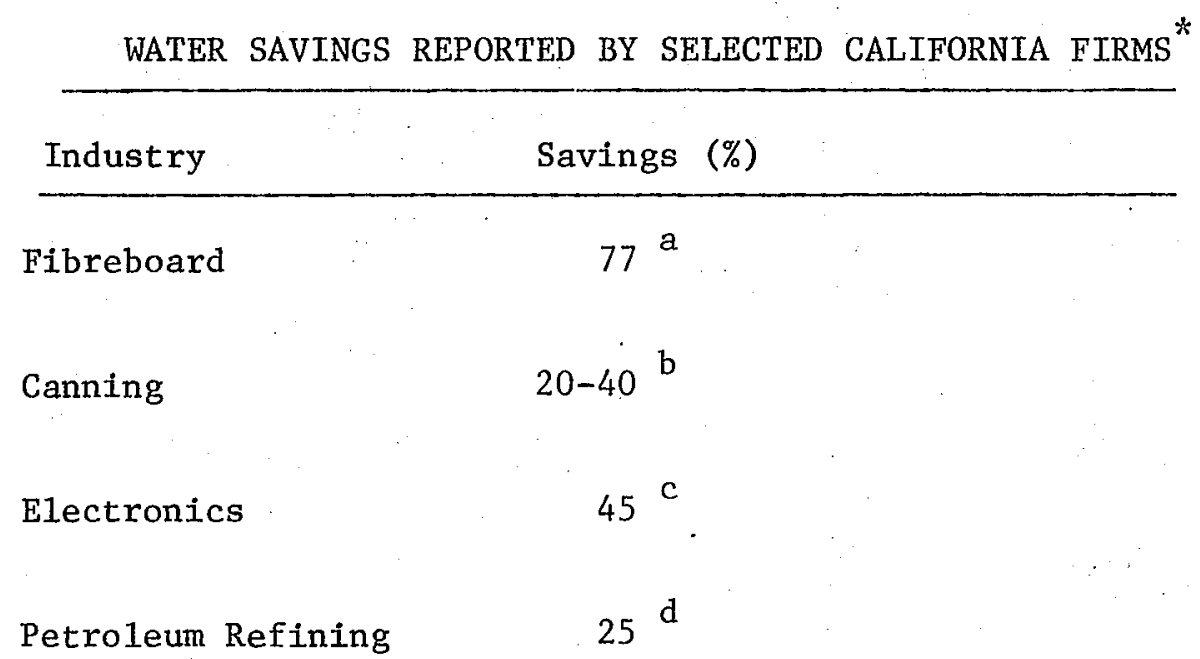

* A11 findings reported at the Drought Conference on Industrial Water Allocation and Conservation, Sheraton Inn-Airport. Concord, July 25, 1977.
a. (64)
b. (79)
c. (69)
d. (88) 
Thus for optimal water supply planning, the pros and cons of both dams and aqueduct construction and water conservation should be clearly set out and evaluated.

Dams regulate water supply for agricultural and urban use and provide flood control, hydroelectric power, and lakes for recreation. But they are costly to build, they employ few people for construction and operation compared with other projects of comparable cost, and the construction time is long. They also have numerous negative environmental impacts: they submerge natural habitats upstream and decrease the water supply to those below; they block movement of fish; they accelerate eutrophication by raising water temperature and trapping nutrients; they upset the saltwater-freshwater balance in estuaries by diminishing the flow rate; they change the evaporative pattern of the water system and increase its evaporation losses; they may contribute to earthquakes by lubricating faults near the dam; they sometimes break, which causes loss of life and property damage; and they eventually fill up with silt which renders them useless.

Water conservation eases the water scarcity and has none of the negative environmental impacts that are associated with dams. Reduced water flow causes problems in wastewater treatment such as clogging of sewer lines and increased concentration of wastewater effluent. The 1atter may in turn increase the wastewater treatment energy requirements. Also, reduced exterior residential water use negatively impacts landscape vegetation. But generally, there appear to be no negative environmental impacts from water conservation comparable to those from dam construction. In the residential sector, conservation is relatively inexpensive and can be implemented almost immediately. In the industrial sector, the cost is relatively low for housekeeping, for selected measures for cooling towers, and, in some cases, for recycling by matching water quality with water needs. These measures also can be implemented quickly. Other measures in the industrial sector have significant water and attendant energy savings but are more costly and require long lead times for installation. Implemented correctly, none of the measures in Table 4 or Appendix A result in decreased product quality or volume. To the extent that materials are needed to implement water conservation, while these represent costs to the firm or household, they result in water and energy savings that are reflected in decreased payments for these resources. They also generate income and employment 
for the sectors that produce and install the materials; so that the net economic impacts may be positive or negative depending on the conservation measure in question.

One of the main objections to relying on water conservation as an alternative to constructing water supply systems for protection against water scarcity is the potential for sustained consumer resistance to behavioral change. To implement some water conservation measures, the consumer, residential or industrial, perceives some inconvenience e.g., reducing showering time from 10 minutes to 5 , or sweeping rather than washing work areas. The burden of conservation is borne by each individual. In dam and aqueduct construction this is not the case. Local residents absorb most of the inconvenience, and the financial cost is borne by the taxpayers. It is usually impossible to determine what portion of one's taxes is assignable to a particular project; besides, the water user does not pay for water at the marginal cost of new supply, but at a lesser rate that is subsidized by tax revenues. So the actions of individuals or firms to conserve water are not rewarded by the price mechanism to the full extent of the savings achieved, and the economic incentive to conserve is dampered. In sum, the costs of dam construction and water conservation are not equally apparent, which hinders the process of evaluation of the alternatives, and hence, of rational water supply planning.

In the context of this problem of potential sustained consumer resistance to water conservation, it is important to distinguish between conservation measures that require continuous attention to the resource being used (such as decreasing showering time and shutting off unused faucets), and those measures that require a one-time installation of a technological improvement (such as installing a shower flow control restrictor or a cooling tower filter). Significant savings can be made from both types of conservation measures, but the objection discussed above applies mainly to the former. The latter approach appears less inconvenient to consumers and employees; flow contro1 restrictors, toilet dams, spring loaded faucets, pressure control valves, footpedals (instead of handles), aerators for faucets, automatic timers, filters, 
and recycling systems can be installed with only an initial inconvenience. (Even these measures involve some behavioral change, though not a continuous one.)

As water savings accrue, the likelihood of reaching the full potential of water conservation will be easier to assess because our experience with water conservation will accumulate. Many outcomes are possible, several of which are discussed here. Consumers and producers could become disgusted with conservation and refuse to cooperate regardless of the cost of new water supply projects or the severity of the drought. Or they could implement technological measures to conserve water and become lax on their management of water consumption, thereby partially or fully offsetting the water savings achieved.

A third possibility is that consumer and producer awareness of present resource waste and conservation potential may increase. This awareness could serve as a stimulus for overcoming the initial inertia connected with changing a behavior pattern, such as collecting shower and sink water while waiting for it to get hot, or shutting off unused faucets in production processes. Once integrated into a daily routine, these new tasks could become no more inconvenient than the myriad of others performed each day.

More information over a long period of time is needed regarding actual water use reductions and consumer and producer attitudes toward the water situation. Some of the data on recent water consumption were discussed above. One survey is available regarding consumer attitudes toward the water problem and the consumers' willingness to conserve water [29]. The survey was conducted throughout California in March 1977. Forty-eight percent of the sample of 962 people surveyed thought the water shortage for the State as a whole was "extremely serious" and an additiona1 $37 \%$ thought it was "somewhat serious." Fifty-two percent think there is a serious water shortage in their county, and $72 \%$ believe there may be one in the foreseeable future. Seventy percent think the State should have a Statewide water plan. Regarding personal cooperation, $87 \%$ indicated they could cut water use by $25 \%$; about half this group said they could do it without any problem while the other 
half indicated it would be inconvenient but they could do it. Fortyeight percent said they could make a cutback of $50 \%$, but most said it would be inconvenient. Fifty-one percent of the people surveyed thought a $50 \%$ reduction would be a severe problem. Ninety-three percent claimed practicing some form of water conservation: less water for bathing, $70 \%$; less frequent car washing, $58 \%$; reduced watering of 1 awns and gardens, $67 \%$. It is interesting to note, however, that two relatively large residential water saving measures that require a one-time installation (toilet dams or plastic bottles, and shower flow control restrictors) had been installed by only $24 \%$ and $16 \%$, respective1y, of the sample interviewed. Thus the potential for large water savings easily achieved is far from exhausted.

Presently, although conservation cannot be relied upon with certainty as a water supply option equivalent to its full potential, it cannot be ignored as it often has been in past water supp1y planning. While it is recognized that surplus capacity for water supply, especially in times of low rainfall, has large social and economic value, to plan for water supply on the basis of past water consumption (per capita residential and per unit output industrial) would result in suboptimal water supply planning. Because of the significant potential of water conservation, its lower cost, shorter implementation time, and more benign environmental impact relative to dam construction, a rational water supply planning process requires that those plans for water supply construction made prior to the availability of recent evidence on water conservation potential should be reassessed.

An itemization of the more detailed results for each sector upon which these general conclusions are based is given below:

- Overall residential water consumption can be reduced by $44 \%$ of average use by implementing the specific water conservation measures in Table 3 . The electricity and natural gas consumption associated with this water use could be reduced by approximately the same percentage. The conservation measures can be implemented immediately at minimal financial outlay per person. 
- The largest residential water use occurs outside the house (landscape irrigation, car washing, etc.). Toilet flushing and bathing are the largest interior water uses. Accordingly, the largest reductions in residential water consumption can be obtained by concentrating conservation efforts on these end uses.

- The highest per capita electricity consumption associated with water use occurs in the South Coastal HSA where $57 \%$ of the State's population resides. The South Coastal and Tulare Basin HSAs have the highest energy requirements for water deliveries the former because of the long distance and predominance of surface water conveyance, the latter because of the importance and depth of groundwater pumping.

- of the four energy components considered (delivery, distribution, heating, and wastewater treatment) energy for water heating dominates the energy uses associated with water consumption. Potential natural gas savings are significantly greater than potential electricity savings due to the more extensive use of gas hot water heaters in California.

- Bathing, the second highest interior residential water use, requires the most energy of all residential water end uses because of the high volume of hot water used; laundry ranks second for the same reason. Accordingly, water conservation measures aimed at reducing water use for bathing (e.g., flow control restrictors and shorter showers) and for laundry (washing only full loads on the shortest cycle) and all measures that reduce water use in the South Coastal and San Francisco HSAs (where the delivery energy requirements are relatively high) would have the largest impacts on water-related energy use. The exception is the Tulare Basin HSA where, due to the high energy requirements for groundwater pumping, substantial reductions in energy use could be achieved by reducing exterior water use.

- Overall industrial water consumption and the associated energy requirements for delivery and distribution can be reduced by at least $23 \%$ and $19 \%$, respectively. This estimate is thought to be conservative for two reasons: some industries have already reported greater savings, and lack of data prevented estimates of the full savings potential for various conservation measures and Industries. The conservation measures that can be applied most immediately are:

a. housekeeping measures such as leak plugging, waste reduction, elimination of unnecessary cleaning, turning off pumps and spigots not in use, installing spring loaded faucets and footpedals, etc.;

b. closed-cycle cooling water reductions such as reduction or elimination of blowdown, installation of basin filters, automatic conductivity sensing units, automatic fan control, reduction of drift losses by installing better eliminators; 
c. reuse of process water where extensive retrofitting of equipment is not required.

Because some conservation measures for water recyc1ing require retrofitting or new equipment, not all the savings estimated in this study could be realized in the short run.

- The centers of industrial water consumption are the San Francisco and South Coastal HSA s. Due to the high energy requirements for delivery and distribution, the greatest water-related energy use also occurs in these regions. Accordingly, relatively large and immediate water savings can be made by implementing the conservation measures listed above in these areas. From the data gathered thus far, the greatest savings potential among the large industrial water users occurs in the Paper and Petroleum sectors. Therefore, a tentative conclusion is that large savings could be effected by concentrating waterconservation efforts in these sectors. This bears further investigation and does not imply that significant savings are not achievable in other sectors. Special attention should be given to food processing because it is the largest industrial water user. 
APPENDIX A

INDUSTRY CONSERVATION MEASURES

The following industry-specific water conservation measures were compiled from the EPA Development Documents for Proposed Effluent Limitations Guidelines [45] and from [43]. They are the basis for Table 4, Water Conservation Measures Applicable to Industry. They are included to provide an indication of the possibilities for industrial water conservation; however, it is important to keep in mind that each firm is a specific case with its own water quality, atmospheric, capital equipment, and quality control problems that require individual examination and application of the water conservation principles listed.

A section at the end of this appendix is devoted to water conservation in closed-cycle cooling towers. This material is derived from the water conservation measures implemented at the Lawrence Berkeley Laboratory cooling towers. 
A) Canned, cured, frozen

1) Housekeeping/Waste

a) Automatic shut-off valves in evaporators, boilers, cookers

2) Cooling

a) Cooling towers

b) Using cooling tower blowdown

3) Effluent Reduction

a) Bulk unloaders to reuse conveyance \& rinsewaters

b) Cleaning of plants with a high pressure steam cleaning system.

c) "Counter-current" flow system

B) Sugar Refining

1) Housekeeping/Waste

a) Recover spilled sugar by sweeping instead of washing

b) Recover all floor, wash drains, sweet water

c) Recovery of waste water with lower sucrose concentration

d) Reduction in volume of wash water used to sweeten off bone char \& carbon colums

2) Cooling

a) Cooling towers to recycle barometric condenser cooling water

3) Effluent Reduction

a) Elimination or reduction in use of ion exchange as an organic color remover

b) Minimum contact time between sugar beets \& flume water [ $45 \mathrm{c}$,

c) Dry handling procedures

d) Flume water recycling

e) Dry pulp conveyor system [45a,

pp 83-91] pp 77-81] 

1) Food
B) Sugar Refining

C) Dairy
3) Effluent Reduction (continued)

f) Handling of lime muds:

1) Low water dilution/air pump conveyance

2) Recovered, recalcinated for reuse

1) Housekeeping/Waste

a) Water shut off valves

2) Cooling

None

3) Effluent Reduction

a) Cone-type silo tank

b) Filler drip shield

c) Interlock control

d) Ice cream filler drip shields

e) Novelty collection system

f) Product recovery can system

g) Non-leak portable damage package unit

h) Case washer control

i) C.I.P. systems-reuse type

j) Automated continuous processing

k) H.T.S.T. recovery system

1) Product rinse recovery

m) Post-rinse utilization

n) Air blowdown

o) Ice cream rerun system [45d]

pg 75

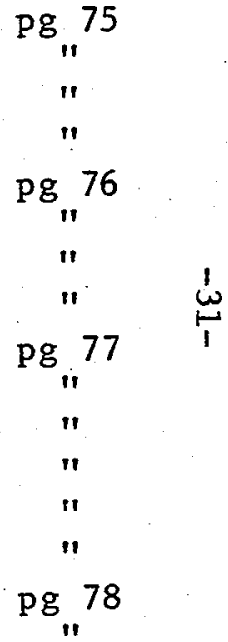

[50f]

pg 72

1) Housekeeping/Waste

a) Replace all wash water valves with squeeze or press-to-open valves

b) Install foot-pedal hand-washing and drinking fountain water valves

c) Replace all drilled spray pipe systems with spray nozzles

d) Install automatic control for sprays 
2) Cooling

a) Replace product chillers with chillers using

a cryogenic 1iquid

b) High pressure water spray systems

3) Effluent Reduction

a) Reuse boiler blowdown

b) Automatic I. P. system

c) Use lowest quality of water satisfactory for

\section{the arocess}

2) Petroleum and Coa1

Product

1) Housekeeping/Waste for wash down water

2) Cooling

a) Subsituting an air exchanger in place of cooling water sprays

b) Substitution of air in place of water coolers pg 98

c) Blowing down from a high pressure level of steam generation to a lower level

d) Use of vacuum pumps in place of steam jet ejectors

e) Reuse of process condensate

f) Install level gauge on water blowdown points

g) Replace water seal on a flarestack with a pg 97 molecular seal 
3) Effluent Reduction

a) Vessels containing heavy oils should be flushed with a lighter oil before cleaning

b) Separate water and oil drains on pump and compressor pads

c) Cleaning water drained to a sump with skimming device

3) Pulp and Paper

A) Pulp and Paper

1) Housekeeping/Waste

a) Self cleaning showers

[45h]

pg 103

2) Cooling

a) Utilize vacuum water for cooling of heat exchanger pg 102

3) Effluent Reduction

a) Recycle white water

b) Reuse of clarified effluent

c) Reduction of seal water

pg 100

pg 101

pg 102

4) Chemical

and Allied

Products

A) Chemicals

1) Housekeeping/ Waste

a) None listed

2) Cooling

a) Cooling towers

pg 79

3) Effluent Reduction

a) Recycle direct contact process water

Pg 81 
B) Soaps and Detergents

1) Housekeeping/Waste

None listed

2) Cooling

[45k]

a) Change operating techniques associated with barometric condensors or replace them with surface condeners

3) Effluent Reduction

a) Installation of additional water recycling Piping and tankage

b) Identify and untangle waste water lines which lead to sewers

5) Lumber and Wood Pro-

duct

A) Millwork, P1ywood and Related Products

1) Housekeeping/Waste

2) Cooling

None listed

3) Effluent Reduction

a) Process water recycle with blowdown to control suspended solids and dissolved organics

b) Process water recycle through a primary clarifier with blowdown of some clarifier effluent \& recycle sludge [45m] pg 174 
5) Lumber and Wood Products

A) Millwork, Plywood \& Related Products

B) Sawmills \&

Planing Mills
3) Effluent Reduction (continued)

c) Process water recycle through primary [45m] clarifier with blowdown being evaporated : pg 174 and some evaporator condensate being utilized for makeup.

d) Process water recycle with blowdown passing " through chemical coagulation system

1) Housekeeping/Waste

a) Reducing flow to minimum volume

b) A11 mill clean-up without use of water

c) Store unprocessed wood on land, sprinkle with water

d) Install special flow control systems

pg 240

pg 242

2) Cooling

a) Cooling water discharged in cooling pumps, turbines, or condensers by way of closed conduits.

b) Saw cooling water usage and chain belt lubricating water usage should be minimized

3) Effluent Reduction

a) Dip vats covered to keep out precipitation

pg 242 and equipped with an apron to catch all dripage

b) Clean up water used for make up

c) High pressure steam hoses

d) Scraping mixing tanks \& other surfaces to remove glue residue

e) Wash water recycle 
5) Lumber and Wood Pro-

ducts

B) Sawmills \& Planing Mills

6) Stone,

Clay,

Glass

A) F1at Glass

B) Cement
3) Effluent Reduction (continued)

f) Split-Recycle System (for single-product pg 266 plants)

g) Use of primary clarifier

h) Use of diatomaceous earth filter

i) Use of spray nozzles to keep logs moist

pg 268

[45p]

pg 79

2) Cooling

3) Effluent Reduction

a) Recycling washers

b) Diatomaceous earth filters

$"$

"

1) Housekeeping/Waste

[450]

a) Removing accumulation of dust from roofs \& buildings for return to process

b) Paving areas for vehicles to minimize solid

pg 53 spillage

2) Cooling

a) Cooling Towers $\quad \mathrm{Pg}_{\text {" }} 52$

3) Effluent Reduction

a) Use slurry water to handle some waste water generated 
7) Primary Metals

A) Blast Furnace \& Basic Steel Products

1) Housekeeping/Waste a) Use of steam to remove volatile compounds

[45q] pg 174

2) Cooling

a) Cooling Towers

b) Spray Ponds

c) Recycle quench wastes

pg 175

d) Reuse blowdown water in a non-sensitive process pg 204,217,218,226

e) Add make-up water and recycling water into spark-box spray system

f) Demineralize blowdown and return condensate to system

pg 200,203

3) Effluent Reduction

a) Distillation $\&$ incineration of coke plant waste loads in controlled combustion system

b) Carbon absorption

c) Waste water recycle system

d) Gas scrubber water on a tight recycle system.

pg 175

"

pg 200

pg 194

B) Primary Metals (Non-Ferrous)
1) Housekeeping/Waste

a) F1ow Restrictors in Waste Water Feed Lines

[45r]

pg 77

2) Cooling

a) Freezing

b) Add wetting agent to rinse water

c) Install air or ultrasonic agitation

pg 100

pg 82

3) Effluent Reduction

a) Installing counter flow rinse tanks \& ion exchange

b) Evaporation recovery

c) Reverse osmosis 
SECTOR

INDUSTRY

7) Primary

Metals

b) Primary Metals (non-ferrous)
3) Effluent Reduction (continued)

d) Electrodialysis

e) Electrolytic Stripping

f) Carbon Adsorption

g) Liquid-Liquid Extraction

h) Drag-out Reduction

i) Use of Conductivity Meters in Final Rinse pg 101

pg. 104

pg 107

pg 107

pg 82

pg 82 
Water Conservation Potential for Closed Cycle Cooling Towers

Water losses from closed-cycle cooling towers occur from blowdown, evaporation and drift loss. Blowdown is the deliberate expulsion of water from the basin to prevent excessive buildup of salt concentration in the tower water. Evaporation occurs as the water falls through the cooling tower: The rate of evaporation depends upon the heat load imposed upon the tower and upon the atmospheric conditions. Drift losses consist of the tiny droplets of water which are thrown out of the tower stack by the action of the tower fan.

The conservation measures listed below are designed to reduce blowdown, evaporation and drift losses to a minimum. They have been implemented on 37 cooling towers at LBL. Most of these towers have a cooling capacity of approximately four megawatts.

It should be pointed out that each facility has its own particular cooling requirements, types of equipment, makeup water quality, atmospheric conditions, etc. so that it is difficult to generalize about conservation procedures. The following is to illustrate what measures can be explored. Specific procedures must be developed on a case by case basis.

1. Reduce blowdown to a minimum.

The quality of the makeup water at LBL is quite good so that the blowdown can be reduced to a very low value. One effective method to accomplish this is to control the rate of blowdown with a solenoid valve actuated automatically when the salt concentration of the basin water exceeds a predetermined value. This value of salt concentration (conductivity) can be set as high as is practicable without causing undue scaling or otherwise adversely affecting the tower operation. This reduction in blowdown has resulted in savings at LBL of approximately 1700 gallons per day per tower. In addition to salt 
concentration, dust, weedseeds, debris etc. also adversely affect the water in the tower basin. The following procedures were implemented at LBL to alleviate this situation:

a. Screens and side stream filters (progressively 50, 10 and 1 micron) were installed to remove suspended solids.

b. These screens and filters were monitored, cleaned, maintained and replaced at regular intervals.

c. The tower basins are drained and cleaned yearly. It is highly recommended that new basins be constructed with sloping sides to facilitate cleaning.

d. The tower water is checked daily for concentration of calcium and magnesium, for conductivity and for $\mathrm{pH}$. The tower is also examined for the presence of algae.

e. Chemical treatment for prevention of corrosion and scale formation and for $\mathrm{pH}$ control is being controlled automatically in some towers. Algae control may also be automatic if chlorine is used.

f. Dispersing agents are added to the tower water to keep solids in suspension so that they may be removed during the slipstream filtration.

g. Sludge from the cleaning of the tower basins or from the filters are collected in barrels and disposed of in a controlled dump.

Consideration has been given to eliminating blowdown altogether and simply recycling the basin water through ion exchange or reverse osmosis units to remove the undesirable constituents. It may be difficult at this time to justify this procedure in terms of the monetary cost.

2. Reduce water losses by control1ing the speed of the tower water fan.

Install automatic water controls such that the temperature of 
the tower basin water (tower water supply to equipment) will determine the speed of the cooling tower fan.

By determining the highest tower water supply temperature which can be used to cool the particular equipment, and using this as the basin water set temperature for the fan controls, one can avoid running the fan unnecessarily or at excessive speeds. This will save electricity, will reduce the drift loss (which is caused by the air movement from the fan) and will probably reduce evaporation.

If this procedure is used, heaters should be installed in the fan motors to prevent condensation when the motors are not running.

3. Drift losses can also be reduced by improving the efficiency of the drift eliminators. The Cooling Tower Institute code limits drift loss to $0.2 \%$ of the circulation rate of water over the tower. 
APPENDIX B

METHODOLOGY AND DATA FLOW

\section{Residential Sector Scenario Construction}

The calculation of residential water and energy use and water conservation potential entails the following steps:

- Present interior and exterior water use per person is estimated for each HSA. Interior use per person is assumed to remain constant over geographical regions of the State, but exterior use is calculated separately for each HSA because water use for landscape irrigation and swimming pools differs widely across the State. Interior use is then broken down into major end uses: toilet flushing, bathing, laundry, dishwashing, cooking, bathroom sink, utility sink.

- For each water end use the associated energy use is estimated on an HSA basis for the following categories: delivery from surface and groundwater, distribution, heating, and wastewater treatment. For exterior use, only delivery and distribution energy use apply. Distribution requirements were calculated only for the two most populated HSA's (San Francisco and South Coast) because of the paucity of data. Energy use for delivery for each HSA was calculated separately because of differences in the distances over which surface water is conveyed, the depth of groundwater, and the proportion of ground-to-surface water use. Energy use for waste water treatment was also estimated for each HSA based on the estimated degree of treatment in each HSA and the size of the treatment plant. The derivation of the estimates for the energy requirements associated with water use are given in Appendix C. 
- Next, water conservation measures for each end use were listed and the approximate reductions in water use from their implementation were estimated. Per Capita water and energy consumption for each end use were extrapolated to 1977. The 1977 population for each HSA was estimated by aggregating 1975 county population figures [22, p. 7] to HSA's [19], then projecting these figures at the average annual statewide population growth rate for the period 1970-1975. This rate is 1.06 per cent per year [22, p. 7]. Estimated 1977 population by HSA is presented in Table 11.

- The savings of water and energy due to the water conservation measures were calculated and a revised estimate was made of water and energy consumption with water conservation factored in. These estimates scale with the rate of conservation implementation; i.e. the savings at $100 \%$ implementation are twice those realized at $50 \%$ implementation.

The steps outlined above are displayed in the following flow chart (Figure 3). The chart a1so denotes the source of data for each component in the calculation.

\section{Industrial Sector Scenario Construction}

The estimation of water and associated energy use in the industrial sector proceeds on the basis of sectoral rather than end use categories.

- First the industries that account for most of the industrial water consumption in California are determined and examined individua11y.

- Fresh and brackish water use by industry and HSA are estimated for 1970, the most recent year that data are available [40]. 
Table 11

Estimated 1977 Population by Hydrologic Study Area

HYDROLOGIC STUDY AREA

1. NORTH COASTAL

2. SAN FRANCISCO BAY

3. CENTRAL COASTAL

4. SOUTH COASTAL

5. SACRAMENTO BASIN

6. DELTA-CENTRAL SIERRA

7. SAN JOAQUIN BASIN

8. TULARE BASIN

9. NORTH LAHONTAN

10. SOUTH LAHONTAN

11. COLORADO DESERT TOTAL
POPULATION

291,705

$4,788,974$

909,065

$11,723,888$

$1,257,227$

499,634

471,286

820,302

44,525

318,723

165,507

$21,290,836$ 


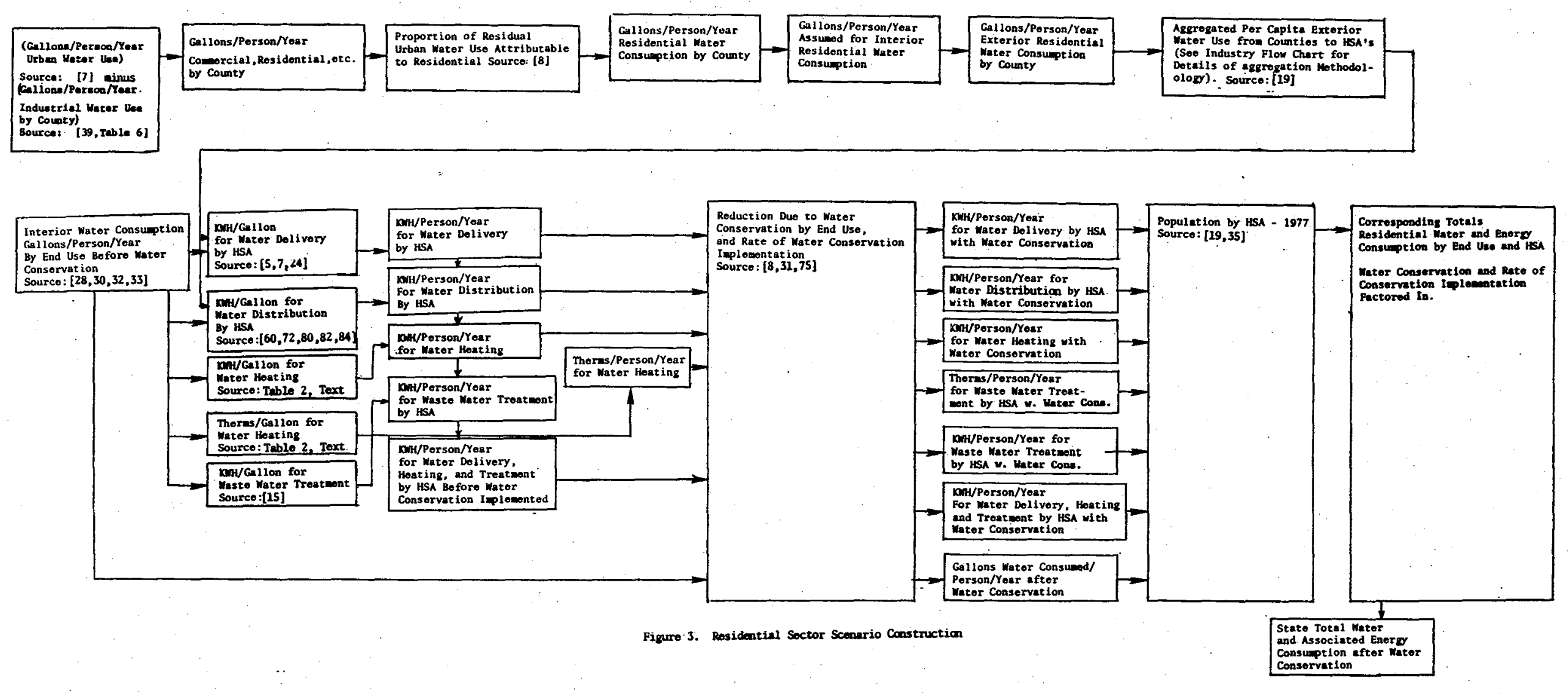


- Next, the energy cost for the delivery and distribution of this water are calculated. The breakdown between surface and groundwater is assumed to be the same for industry as for the rest of urban use. A11 brackish water is assumed to be pumped from rivers with an average required lift of five feet. The energy cost for industrial wastewater treatment has not yet been estimated because of data limitations. On-site treatment varies with each firm and location as does the proportion subsequently discharged to municipal treatment plants. This information is not available through published sources.

- Water conserving measures are then indicated, and wherever possible, quantitative estimates of the savings potential are obtained. Water and the associated energy use by industry and HSA are then extrapolated to the summer of 1977. The extrapolation is based on seasonally adjusted employment figures in each industry [62].

- Finally, an estimate is made of the potential reductions of water and energy consumption as water conserving measures are applied.

These calculations are presented in the following flow chart. (Figure 4) The source for each component is also indicated. 


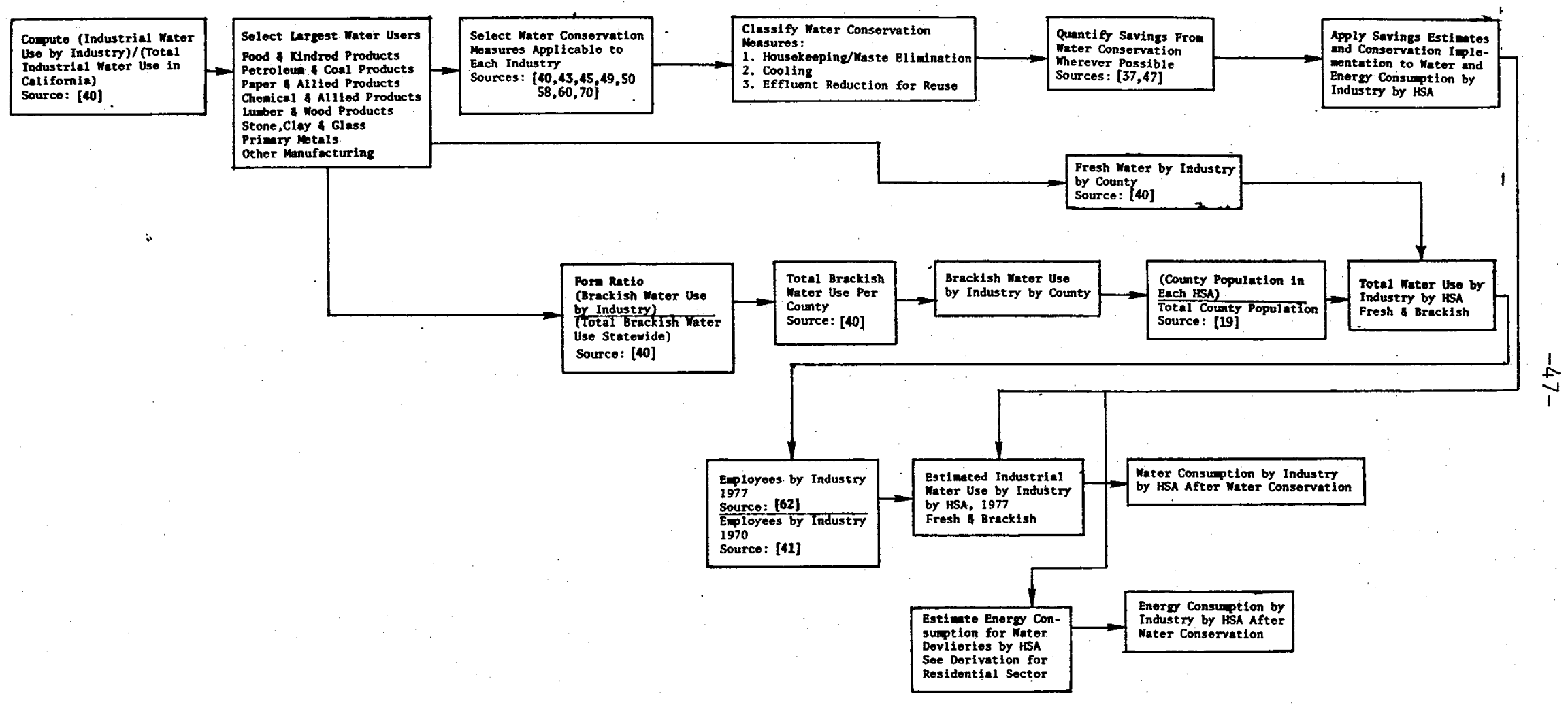

P1 gure 4. Indestrtel Sector Scenario Construction 
APPENDIX C

DERIVATION OF ENERGY REQUIREMENTS FOR WATER DELIVERY, DISTRIBUTION, HEATING, AND WASTEWATER TREATMENT

\section{Water Delivery}

Calculation of the energy requirements for water deliveries requires three types of information:

(1) the water sources for each area, both ground and surface;

(2) the energy requirements for delivery from each source; and

(3) the fraction that each source constitutes of total urban water deliveries in each area.

The major sources of urban water in California are the Central Valley Project(CVP), the State Water Project (SWP), local surface supplies, imports from out of state, and groundwater. The deliveries are estimated by HSAs. These are shown in Figure 2. For each HSA, water deliveries and the associated energy requirements by the CVP and SWP are estimated. 'The estimates are based partially on published sources $[5$, pp. 24,$32 ; 23$, pp. 4,7] and partially on discussions with personnel connected with operation or use of the projects $[48,52,60,68,72,78,89]$. Since the SWP does not break out urban water deliveries by HSA, total deliveries were distributed to the appropriate HSA and split between urban and agricultural use based on the location and name of the agencies to which water was delivered. Water delivered to irrigation districts was assumed to be entirely for agricultural use, and water to municipal water districts entirely for urban use. The resulting distribution was compared with the totals for agricultural and urban water use in Ref. $5 \mathrm{p} .36$. The distribution was adjusted based on probable water use and population density in each geographic location. 
Local surface water supplies and imports with the attendant energy requirements were included where data are readily available-the Hetch Hetchy and Mokelumne Aqueducts in the San Francisco HSA [60, 65] and the Los Angeles and Colorado River Aqueducts in the South Coastal HSA [3, 14, 15]. These were added to the estimates for the CVP and SWP to obtain total estimated surface water deliveries by HSA and the associated energy requirements (see Table 12). Water deliveries and the attendant energy requirements from the California Aqueduct to the South Coastal HSA were excluded from the calculation because these deliveries were stopped on March 1, 1977.

To calculate groundwater use in each HSA, the surface water deliveries estimated above were subtracted from total urban water use in each HSA [7, p. 7]. It is assumed that the entire residual is attributable to groundwater supply; the amount attributable to local surface water supplies, aside from the four major aqueducts discussed above, was not estimated due to the lack of data. The surface water deliyeries used for groundwater recharge that is subsequently pumped again for urban use is ignored, but the control total for urban water use agrees with the published figure in [7]. Estimates of the energy required for groundwater pumping are based on the average groundwater depth in each HSA $[16, p .7]$, and on an assumed pump efficiency of $59.5 \%[16$, p. 5]. The average well depth in each area pertains to agricultural wells. The average depth for urban use may vary from this estimate. The data on groundwater depth are reported by Hydrologic Planning Basin rather than by HSA. The correspondence between the two is shown in Table 12. Also shown for each HSA are the estimated energy requirements for groundwater pumping, average groundwater depth, and total urban water use. The estimated energy requirements for groundwater pumping weighted by the estimated fraction of total urban water use supplied from groundwater, are combined with the energy requirements for surface water deliveries, weighted by the corresponding fraction for surface water use. This yields an overall energy requirement for urban water delivery in each HSA (Table 12).

An additional energy requirement is included for the industrial sector to account for pumping of brackish water. A five foot lift and a pumping efficiency of $79 \%$ is assumed for all brackish water consumption; the resulting energy requirement is .02 Wh per gallon. 
TABLE 12

ENERGY REQUTREMENTS FOR URBAN WATER DELIVERIES

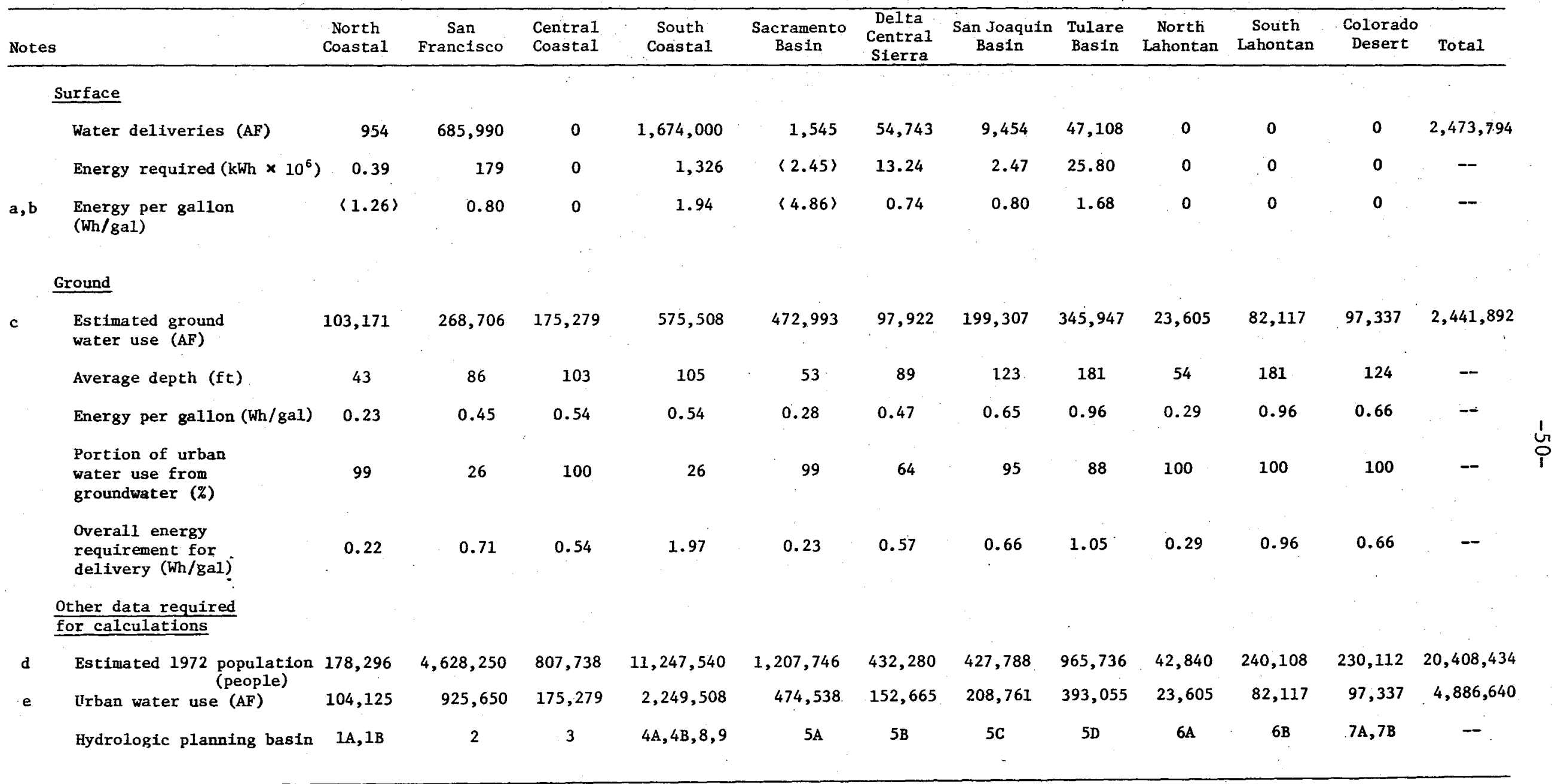

Notes: a 325,851 gallons per acre foot.

b ( ) energy generated.

c Urban water use minus surface water deliveries.

d 1970 population from [7,p.7] increased by $2 \%$.

e Based on annual per capita urban water use from $[7, p .7]$ 


\section{Distribution}

The unit energy requirements for water distribution within urban areas are calculated from estimates of both water deliveries by municipal water departments and the attendant energy expenditures. As there appear to be no published sources for the energy data, personal communications with water department personnel were relied upon. The lack of published data prevented estimation of the distribution energy requirements for a11 urban areas in the time alloted for this study. Estimates were made for the San Francisco and South Coastal HSAs where three-quarters of the State's population resides. The data are shown in Table 13. The unit energy requirement is obtained by dividing total electricity requirements for each HSA by the corresponding urban water deliveries. Water Heating

A statewide saturation of $85 \%$ gas hot water heaters and $11 \%$ electric water heaters is assumed (based on [2]). The calculation of the energy consumption for heating water is based on assumptions of $70 \%$ efficiency for gas hot water heaters, $99.5 \%$ efficiency for electric hot water heaters, and 8.32 Btus per gallon per degree fahrenheit to heat water from $60^{\circ} \mathrm{F}$ to $140^{\circ} \mathrm{F}$ (source: [27], Tables for Heat Capacity of Water). The estimates are for the incremental energy requirements only and do not include standby losses from the water heater. The calculation is made as follows:

$\left(\left(8.32 \mathrm{Btu} / \mathrm{G} /{ }^{\circ} \mathrm{F} \times 80^{\circ} \mathrm{F}\right) / .7\right) / 100,000 \mathrm{Btu} / \mathrm{Th}=.00952 \mathrm{Th} / \mathrm{G} /{ }^{\circ} \mathrm{F}$ $\left(\left(8.32 \mathrm{Btu} / \mathrm{G} /{ }^{\circ} \mathrm{F} \times 80^{\circ} \mathrm{F}\right) / .995\right) 3413 \mathrm{Btu} / \mathrm{kWh}=.196 \mathrm{KWh} / \mathrm{G} /{ }^{\circ} \mathrm{F}$

\section{Wastewater Treatment}

Estimates of the energy consumption per gallon of wastewater treated are taken from reference [15], Table 5. The figures do not include energy recovered from digester gas, offsite energy for chemical production, or energy for construction of the plant. Exfiltration from 
TABLE 13

ENERGY REOUIREMENTS FOR WATER DISTRTBUTION WITHIN THE SAN FRANCISCO AND SOUTH COASTAL HYDROLOGIC STUDY AREAS

\begin{tabular}{|c|c|c|c|c|c|}
\hline$\underline{\mathrm{HSA}}$ & Water Department & $\frac{\text { Water Deliveries }}{\text { (acre-feet) }}$ & $\begin{array}{l}\text { Total Energy } \\
\text { Required } 10^{6} \mathrm{kWh}\end{array}$ & $\frac{\text { Unit Energy }}{\text { Required Wh/g }}$ & gal \\
\hline \multirow[t]{3}{*}{ San Francisco } & $\begin{array}{l}\text { San Francisco } \\
\text { City Water Dept. }\end{array}$ & $105,852^{a}$ & $49^{b}$ & & \\
\hline & $\begin{array}{c}\text { East Bay Municipal } \\
\text { Utility District }\end{array}$ & $250,000^{c}$ & $48^{c}$ & . & \\
\hline & TOTAL & 355,852 & 97 & $.84^{\mathrm{d}}$ & \\
\hline \multirow[t]{4}{*}{ South Coastal } & $\begin{array}{l}\text { Los Angeles } \\
\text { Aqueduct }\end{array}$ & 480,000 & $199^{e}$ & - & \\
\hline & $\begin{array}{l}\text { Colorado } \\
\text { Aqueduct }\end{array}$ & $1,212,000$ & $0^{\mathrm{f}}$ & & \\
\hline & $\begin{array}{l}\text { San Diego City } \\
\text { Water Dept. }\end{array}$ & 180,700 & $13.6^{\mathrm{g}}$ & & . \\
\hline & TOTAL & $1,872,700$ & 212.6 & .35 & \\
\hline
\end{tabular}
a. [83] .
e. $[72]$.
b. $[84]$.
f. $[76]$.
c. $[60]$.
g. $[82]$.

d. 325,851 gallons per acre foot. 
interior residential use is ignored. All water used inside the house is assumed treated. The pairing of HSAs with the type of wastewater treatment is based on conversations with Professor William Oswald [54] and Dr. David Spath [53]. The estimates reflect the present type of treatment, or the type expected when construction in progress is complete. The size of the plants was estimated from inspection of the average daily flow data for municipal waste water treatment facilities in each HSA [39, Table 1]. The size and type of treatment assumed for each HSA are summarized in Table 14. 
Table 14

WASTEWATER TREATMENT FACILITIES : ASSUMED PLANT SIZE AND LEVEL OF TREATMENT

\begin{tabular}{lcc}
\hline \multicolumn{1}{c}{ HSA } & Size & Level of \\
\hline North Coastal & $10^{6}$ Gallons per Day & Secondary \\
San Francisco Bay & 100 & Primary \\
Central Coastal & 1 & Secondary \\
South Coastal & 100 & Secondary \\
Sacramento Basin & 1 & Secondary \\
De1ta-Central Sierra & 100 & Primary \\
San Joaquin Basin & 1 & Primary \\
Tulare Basin & 1 & Primary \\
North Lahontan & 1 & Secondary \\
South Lahontan & 1 & Secondary \\
Colorado Desert & 1 & Secondary \\
\hline
\end{tabular}




\author{
APPENDTX D \\ RESIDENTIAL AND INDUSTRIAL WATER \\ AND RELATED ENERGY CONSUMPTION BY \\ RESIDENTIAL END USE, INDUSTRIAL SECTOR, \\ AND HYDROLOGIC STUDY AREA
}


RLSIOLINTIAL WATER CONSUMPTION DURING 1977 (MILLIONS CF GALLONS)

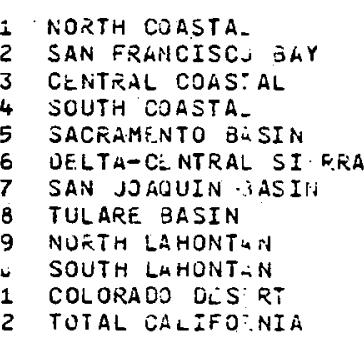

TOILLT
2602
43699
8295
146980
11472
4559
4360
7485
406
2968
1514
194279

BATHING
2123
34960
6030
85584
9178
3047
$344 J$
5388
325
2327
1248
152423

LAUNORY
932
15296
2964
37446
4016
1596
1505
2620
142
1018
529
18603

OISH
WASHING
399
6556
1245
16056
1721
584
645
1123
61
436
227
29147

COOKING
319
5244
995
12833
1377
547
516
898
49
348
181
23313

$3 A T H R C O M$
SIAR
213
$343 E$
654
8558
918
355
344
579
33
233
121
15542

JTILITY

SINK
133
2184
415
5346
573
228
215
374
20
145
75
0709

IXTERIOF

4146

TOTAL

$22962 \quad 44115$

<80693 553496

$19370 \quad 105314$

$30610 \quad 41576$

$59114 \quad 78 \div 02$

79113
1713

12447

2749
19864

23834

1119250

KE SIUENTIAL WATER CONSLMPTION AT 100 PERLEAT IMPLE:TENTATICY

(MILLIONS OF GALLONS)

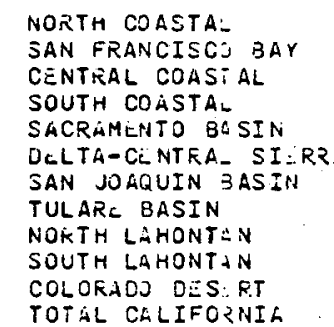

- $\therefore$

$\begin{array}{rr} & \\ \text { TOILET } & \text { BATHING } \\ 1917 & 926 \\ 31464 & 15033 \\ 5973 & 2854 \\ 77626 & 35851 \\ 8260 & 3946 \\ 3283 & 1568 \\ 3696 & 1479 \\ 5389 & 2575 \\ 293 & 140 \\ 2094 & 1400 \\ 1087 & 526 \\ 139881 & 66832\end{array}$

COOKING
303
4982
346
12196
1308
526
490
353
46
332
172
22148

BATHRCJM SIA
136
$17+8$
332
4279
439
132
172
299
116
116
50
7771
JTILITY

$\begin{array}{rr}\text { IINK } & \text { LXTEKIOR } \\ 67 & 2073 \\ 1092 & 53026 \\ 207 & 11481 \\ 2673 & 140347 \\ 287 & 38030 \\ 114 & 9685 \\ 107 & 15365 \\ 187 & 29557 \\ 10 & 857 \\ 73 & 6224 \\ 38 & 4433 \\ 4854 & 311917\end{array}$

TOTAL

6419

125267
25023 314995
56759 56759 17128
22325 41777 1520
10972 $\in 898$

$\therefore, \ldots, \quad, \quad, \quad$,


SLECTRICITY CONSUMPTICN FLR RESIDENTAIL WATER USE (MILLIONS CF KILOWATT-HJURSI

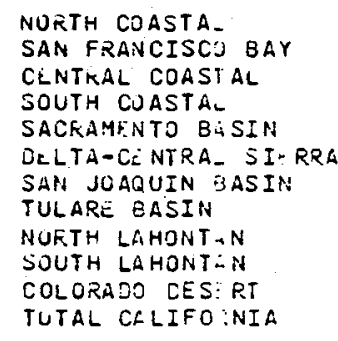

$\begin{array}{rr}\text { TOILET } & \text { BATHING } \\ 4 & 29 \\ 73 & 483 \\ 14 & 92 \\ 349 & 1318 \\ 16 & 124 \\ 3 & 47 \\ 4 & 45 \\ 10 & 80 \\ 2 & 4 \\ 6 & 33 \\ 3 & 27 \\ 482 & 2271\end{array}$

LALNORY
19
315
62
828
81
31
30
53
3
21
11
1451

DISH

COOKING

BA THRCJM

THRCJM
SINK
3
+8
9
132
12
5
5
8
0
3
2
228

JTILITY

CXTERICK

TOTAL

$\begin{array}{rr}5 & 0 . \\ 50 & 9 \\ 17 & 2 \\ 246 & 42 \\ 23 & 2 \\ 9 & 0 \\ 8 & 9 \\ 15 & 1 \\ 1 & 1 \\ 6 & 1 \\ 3 & 0 \\ 424 & 5 \subseteq\end{array}$

2
30
6
82
8
3
3
5
0
2
1

167
15
$E 5$
1
1
20
62
1
96

1216

211
3648

284

1109

$\frac{114}{234}$

10

85
43
6017

LLECTRICITY CONSUMPTION AT 10, PERCEITT IMPLEMENTATION (MILLICNS OF KILOWATT-HOURS)

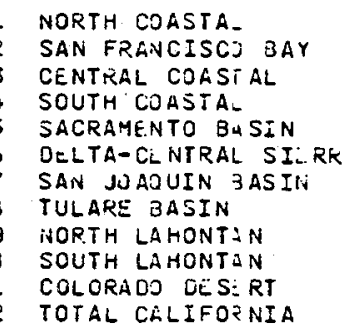

$\begin{array}{rrrrr}\text { TOILIT } & \text { BATHING } & \text { LAUNORY } & \text { BISH } \\ 3 & 22 & 16 & 3 & \\ 53 & 208 & 271 & 53 & 0 \\ 113 & 39 & 51 & 10 & 9 \\ 252 & 567 & 712 & 145 & 2 \\ 11 & 53 & 76 & 14 & 40 \\ 2 & 26 & 27 & 5 & 2 \\ 3 & 29 & 26 & 5 & 0 \\ 7 & 34 & 45 & 9 & 0 \\ 5 & 2 & 2 & 0 & 1 \\ 4 & 14 & 18 & 4 & 0 \\ 2 & 7 & 9 & 2 & 1 \\ 347 & 977 & 1248 & 254 & 56\end{array}$

3ATHRCIM

JTIITY
SINK
1
15
3
41
4
1
1
3
0
1
1
71

XTERIO

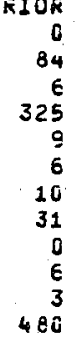

TOTAL 
NATURAL GAS CONSLMPTICN FOR RESIDENTIAL WATER US (MILLIONS JF THERMS)

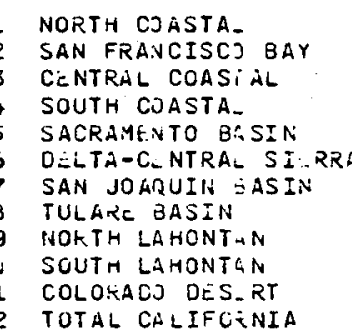

\begin{tabular}{|c|c|c|c|c|}
\hline & & & DISH & \\
\hline TOILET & BATHING & LAUNORY & WASHING & COOKING \\
\hline & 10 & 7 & 2 & 0 \\
\hline 0 & 257 & 108 & 30 & 0 \\
\hline 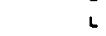 & 3 & 21 & 6 & 0 \\
\hline o & 385 & 265 & 73 & 0 \\
\hline i & 41 & 28 & 8 & 3 \\
\hline ¿ & 26 & 11 & 3 & $j$ \\
\hline c & 15 & 11 & 3 & 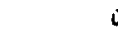 \\
\hline$i$ & 27 & 19 & 5 & 0 \\
\hline & 1 & 1 & $\varepsilon$ & 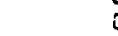 \\
\hline$c$ & $1 \mathrm{~J}$ & 7 & 2 & 0 \\
\hline 5 & 5 & 4 & 1 & a \\
\hline$i$ & 699 & 481 & 132 & $i$ \\
\hline
\end{tabular}

BATHRCJM

SIAC
1
16
3
39
4
2
2
3
0
1
1
70

$\begin{array}{rr}\text { JTILITY } \\ \text { SINK } & \text { EXTERICE } \\ 1 & 0 \\ 10 & 0 \\ 2 & 0 \\ 25 & 0 \\ 3 & 0 \\ 1 & 0 \\ 1 & 0 \\ 2 & 0 \\ 0 & 0 \\ 1 & 0 \\ 0 & 0 \\ 45 & 0\end{array}$

TOTAL 20
321 61
786

NATURAL GAS CONSUMPTION AT

(MILLIONS OF THERMS) SAN FRANCISC? BAY CENTRAL COASI SOUTH CJASTAL DELTA-CLNTRA_- SI_RRA SAN JOAQUIN TASI'T TULARE BASIN

NORTH LLHONTLN

SOUTH LAHONTAN

COLORA DE DES:RT

$\begin{array}{rr}\text { TOILET } & \text { BATHING } \\ 6 & 4 \\ i & 0 B \\ j & 23 \\ 5 & 156 \\ \vdots & 18 \\ \vdots & 7 \\ \vdots & 7 \\ 5 & 12 \\ 5 & 5 \\ \vdots & 5 \\ j & 2 \\ 6 & 3 i 1\end{array}$

LALNOFY
6
93
18
228
24
16
9
16
1
6
3
414

OISH
WASHING
1
18
3
43
5
2
2
3
0
1
1
78

COCKING
$j$
0
3
0
0
0
0
0
0
0
0
$j$

BATHROJM SIAK

IAC
6
8
1
19
2
1
1
1
3
1
0
35

TIIITY
SINK
0
5
2
12
1
1
0
1
0
0
0
22

EXTERICK

TOTAL

12
191
36
468
50
20
19
33
2
13
7
850 

SAN FRANCISCO BA CENTFAL COASTA SOUTH COASTAL SACRAMLN 10 EASIN DELTA-CENTRAL SILRFA
SAN JOMQUIN BASIN

TULARE BASIA

MCRTH LAHCNTAN

SOUTH LATONTAN

COLOSAUOO DESERT

TOTAL CALIFOENIA

\begin{tabular}{|c|c|}
\hline $\begin{array}{l}\text { FCCD ANC } \\
\text { KIN } L R=D\end{array}$ & $\begin{array}{l}\text { LUMBER } \\
\text { A VO WOOL }\end{array}$ \\
\hline PFCOUCTS & $\begin{array}{c}\text { PFODUCTS } \\
7759\end{array}$ \\
\hline $\begin{array}{r}310 \\
20410\end{array}$ & $\begin{array}{l}1739 \\
2014\end{array}$ \\
\hline 5539 & 13 \\
\hline 24182 & 348 \\
\hline $\begin{array}{r}9670 \\
1605 L\end{array}$ & $\begin{array}{r}12566 \\
1004\end{array}$ \\
\hline $202-8$ & 817 \\
\hline 10750 & 3334 \\
\hline & $18 \leqslant 9$ \\
\hline $1 \div 98$ & 89 \\
\hline 277 & $\begin{array}{r}11 \\
2<15\end{array}$ \\
\hline & \\
\hline
\end{tabular}

TOTAL WATER CCNSUMPTIOV DURING 1977 OFLIONS OF GALLCNS

PAPEF AND CHEMICAL PETROLEUM STONE CLAY ALLIEO ANC ALLIEL AND COAL ANO GLASS
PROCUCTS PROODUCTS PFODUCTS PROOUCTS
PROCUCTS 22104 27766 4503

5509

6743
623 29
255
36

255
36
83527 PODUCTS PZOOUCTS

21171
4589
13056
1075
7347
1122
2781
1
1712
148
53005

17
47516
798
34243
44
13134
118
1021
90
762
74
97727

PRIMARY OTHER TUTAL METALS INDUSTRIES INOUSTRIES METALS O INOUSTRIES INOUSTRIES $00 \quad 14 \quad 38232$ $\begin{array}{rrr}2374 & 9303 & 139634 \\ 97 & 321 & 17864 \\ 6312 & 29665 & 131576\end{array}$ $6312 \quad 29665 \quad 131576$ $\begin{array}{lll}70 & 641 & 45834 \\ 10 & 142 & 23680\end{array}$ $\begin{array}{lll}10 & 142 & 23680 \\ 65 & 571 & 19321\end{array}$ 1
+78
218 $2027 \quad 8263$ 9056 43770
MINIMUR INEUSTETAL

FCCD ANO
KINCRED
PRCOUCT
293
24561
5152
22489
8953
14530
18831
9597
3
18.58
25
10735

LUMBEK PRODUCTS
TOTAL WATER USEAEE 100 PERCENT IMPLEMENTATION

PAPEE AND CHEMICAL ALLIED ANO ALLIED

PETROLEUM STONE CLAY

PYODUCTS PRODUCTS.

NORTH COASTAL CENTRAL COASTAL

SOUTH COASTAL

SACRAMt INTO EASIN

CELTA-CENTRAL SIETEFA

SAN JOAQUIN BAS

NORTH LAHONTAN

SOUTH LAHONTAN

SOUTH LAHONTAN

12 TOTAL CALIFORNIA
7371
$\therefore \quad 1913$

$\begin{array}{r}13 \\ 331 \\ \hline\end{array}$

21.938

954
776

776
3168
$17 \notin 6$

$17 \notin 6$
85

85
10

28324
11052
13883
2252
7979
2755
3372
311
14
0
128
18
41764
20112
4359
12404
1021
6979
1006
2642
1
1626
140
50355

24708

415
17807

23
6830

611
531

0
396
38

38
50318
17.
2926

17
2926
1429
7420
293
800
572
636
9
895
260
15262

PRIMARY OTHER TOTAL

METALS INOUSTRIES INDUSTRIES

$\begin{array}{rrr}0 & 13 & 18760 \\ 2255 & 8837 & 99197 \\ 92 & 780 & 14490 \\ 5997 & 28181 & 132607 \\ 30 & 358 & 25409 \\ 66 & 009 & 34540 \\ 9 & 135 & 21761 \\ 52 & 638 & 17688 \\ 1 & 5 & 1786 \\ 454 & 1926 & 7367 \\ 207 & 100 & 1038 \\ 9173 & 41582 & 344643\end{array}$


ENLEGY PEQUIREMENTS FOF TOTAL WATER DEL+OIST OURING 1977

(THOUSANDS OF KILOWATT-HOURS)

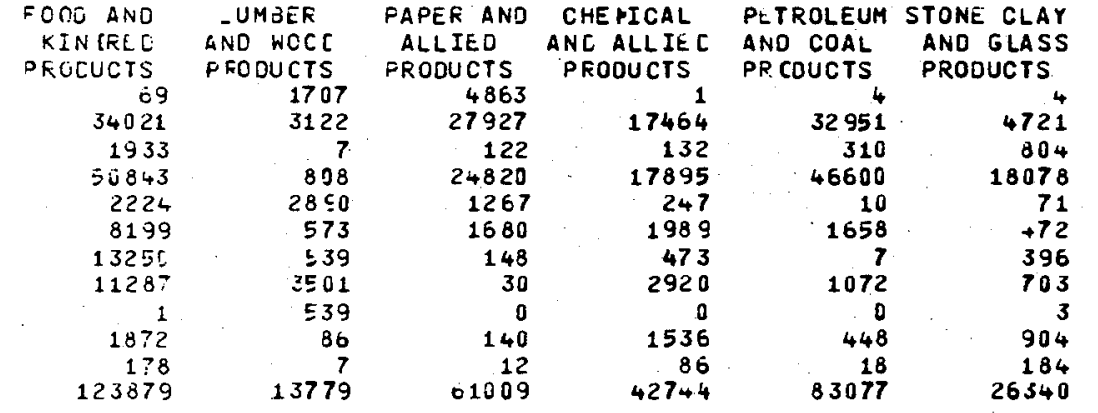

123879
PRIMARY OTHER

TOTAL

METALS, INOUSTRIES INDUSTRIES

$\begin{array}{rrr}0 & 3 & 6651 \\ 3656 & 14+19 & 138282 \\ 49 & 443 & 3800 \\ 14626 & 68822 & 242492 \\ 7 & 87 & 6803 \\ 36 & 365 & 14972 \\ 6 & 94 & 14913 \\ 69 & 705 & 20287 \\ 0 & 2 & 545 \\ 459 & 1946 & 7390 \\ 144 & 69 & 699 \\ 19052 & 86354 & 456835\end{array}$

19052

86354

456835

MINIMUM ENERGY USEAGE FOR TOTAL WATER DEL+OIST 100 PEREENT IMPLEMENTATIJN

SAN FRINCISCO BAY

CENTPAL COASTAL

SOUTH COASTEL

DELTA-ZENT PAL SIEEKA

SAN JO MQUIN BASIA

NORTH LATIONTAN

1 COLOTAUO DESERT

NORTH COASTAL SAN FRANCISCO BAY

CENTRAL COASTAL

SACRAMENTO BAST

CELTA-CENT FAL SIEERA

SAN JOAQUIN BASIN

TULARE BASIN

NOETH LAHONTAN

SOUTH LAHONTAN

COL ORADO DESERT

.

$\begin{array}{rr}\text { FOOD AND } & \text { UUMBER } \\ \text { KINCRED } & \text { AND WOCL } \\ \text { PROOUCTS } & \text { OQOOUCTS } \\ 65 & 1622 \\ 31 E 39 & 29 E 6 \\ 1798 & 7 \\ 47284 & 768 \\ 20 E 8 & 2746 \\ 7625 & 544 \\ 12323 & 512 \\ 10497 & 3326 \\ 1 & 512 \\ 1741 & 81 \\ 166 & 7 \\ 11=207 & 13090\end{array}$

PAPER AND CHEMICAL
ALLIED ANO ALLIEC

PETROLEUM

PRCOUCTS

2431
13964
61
12410
$\in 34$
840
74
15
0
70
6
30505

ODUCTS

AND COAL
STONE CLAY
AND GLASS

PRIMARY

TOUTAL

2
17135
161
24232
5
862
3
557
0
233
9
43200

2
17135
161
24232
5
862
3
557
0
233
9
43200

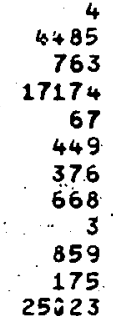

$\begin{array}{rrr}0 & \text { INDUSTRIES INDUSTRIES } \\ 347 & 3 & 4127 \\ 46 & 13598 & 103951\end{array}$

$\begin{array}{rrr}46 & 421 & 3383\end{array}$

$13395 \quad 65381 \quad 198144$

$\begin{array}{rrr}7 & 82 & 5844 \\ 35 & 347 & 12591\end{array}$

$\begin{array}{rrr}6 & 89 & 13833 \\ 65 & 659 & 18573\end{array}$

436

137
18100

1849

18573

1459

40607

43200 . $25 \hat{2} 23$

626
82606 
$-61-$

APPENDIX E

WATER CONSUMPTION IN 1976 AND 1977

FOR SELECTED MONTHS AND WATER DISTRICTS 
APPENDIX E

COMPARISON OF 1976 TO 1977 WATER

CONSUMPTION BY DISTRICT*

Hydrologic

Study Area

Water Period

District

Water Consumption

(106. Gallons)

Percent

1976

1977

Change

(1) North Coastal Eureka 537

Tota1

537

439

439

$-18$

(2)

San Francisco

San Francisco

$1 / 1-5 / 20$

14067

10803

San Jose

$1 / 1-5 / 19$

13967

10757

East Bay MUD

$1 / 1-5 / 19$

27702

19342

Alameda Co. WD 1/1-5/19

3339

2530

Santa Clara

$1 / 1-5 / 3$

2173

1893

San Mateo

$1 / 1-4 / 30$

1286

968

Daly City

$1 / 1-5 / 21$

1061

811

Hayward

$1 / 1-4 / 30$

1487

1081

Sunnyvale

$1 / 1-4 / 30$

2172

1779

Marin MWD

$1 / 1-5 / 22$

2967

1452

No. Marin MWD $1 / 1-5 / 30$

754

513

Santa Rosa

$1 / 1-4 / 30$

1194

934

Contra Costa

10559

9315

Tota1

Co. WD

82728

62,178

$-25$

(3)

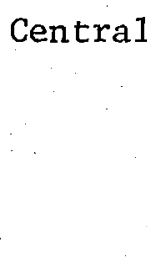

Total
Monterey Bay $1 / 1-4 / 30$

$$
\text { Santa Barbara 1/1-5/1 }
$$

San Luis Obispo

$1 / 1-5 / 1$

Santa Maria

$1 / 1-5 / 1$
1535

1417

602

746

4300
988

1250

605

656

3499 
APPENDIX E

(cont'd)

Hydrologic

Water

Pexiod

Water Consumption

Percent

Study Area

District

(10 ${ }^{6}$ Gallons)

$1976 \quad 1977$

Change

(4)

South Coastal

Los Angeles

$1 / 1-5 / 1$

$56894 \quad 55389$

San Diego

$1 / 1-5 / 1$

$15203 \quad 14678$

Long Beach

$1 / 1-5 / 1$

11542

5976

Anaheim

$1 / 1-5 / 1$

5009

4774

Riverside

$1 / 1-3 / 31$

2724

2412

Oxnard

$1 / 1-5 / 1$

1686

1680

Ventura

$1 / 1-5 / 1$

2105

1789

Tota1

$90,163 \quad 86,698$

$-3$

(5) Sacramento Basin Redding

$1 / 1-2 / 5$

184

221

Chico

$1 / 1-4 / 30$

1076

1018

Total

Alturas

$1 / 1-4 / 30$

64

1324

76

$2457-2012$

(6) Delta-Central Stockton

$1 / 1-4 / 30$

$2457 \quad 2012$

Sierra

Total.

$2457 \quad 2012$

(7) San Juaquin

Sacramento

$1 / 1-4 / 30$

$6263 \quad 6065$ Basin

Modes to

Merced

Sonora

Jamestown
$1 / 1-4 / 30$

$1 / 1-4 / 30$

$1 / 1-4 / 30$

Tota1

9685

2445

2181

$844 \quad 771$

133

129

$-.6$

$-18$

.


APPENDIX E

(cont'd)

Hydrologic

Study Area

Water
District

Water Consumption
$\left(10^{6}\right.$ Gallons $)$
$1976 \quad 1977$

Percent

Change

(8) Tulare Basin Fresno

$1 / 1-4 / 30 \quad 4684 \quad 4040$

Bakersfield

$1 / 1-4 / 30$

3636

3355

Tota1

8320

7395

$-11$

STATE TOTAL

$199514 \quad 172652$

$-13$

* Source: [55] 


$$
-65-
$$

COMPARISON OF 1976 TO 1977 WATER CONSUMPTION BY DISTRICT: SELECTED MONTHS*

\begin{tabular}{|c|c|c|c|c|c|}
\hline \multirow[b]{2}{*}{ HSA } & \multirow{2}{*}{$\begin{array}{l}\text { Water } \\
\text { district }\end{array}$} & \multicolumn{2}{|c|}{ Water Consumption } & \multirow[b]{2}{*}{ Month } & \multirow{2}{*}{$\begin{array}{l}\text { Percent } \\
\text { change }\end{array}$} \\
\hline & & $\begin{array}{c}1976 \\
\left(\times 10^{6} \mathrm{gal}\right. \\
\text { er month) }\end{array}$ & $\begin{array}{c}1977 \\
\left(\times 10^{6} \text { ga1 }\right. \\
\text { per month })\end{array}$ & & \\
\hline \multirow{7}{*}{ San Francisco } & EBMUD & 7950.0 & 3630.0 & 5 & \\
\hline & SFWD & 7868.0 & 5726.0 & 4 & \\
\hline & So. SF & 227.4 & 155.2 & 4 & \\
\hline & San Mateo & 361.2 & 248.2 & 4 & \\
\hline & Los Altos & 337.2 & 255.2 & 4 & \\
\hline & San Carlos & 124.8 & 82.5 & 4 & $\because$ \\
\hline & Tota 1 & 16868.6 & 10097.1 & & -40 \\
\hline \multirow{5}{*}{$\begin{array}{l}\text { Centra1 } \\
\text { Coastal }\end{array}$} & Santa Cruz & 404.2 & 172.0 & 5 & \\
\hline & Santa Barbara & 358.4 & 376.0 & 4 & \\
\hline & Salinas & 251.0 & 242.4 & & \\
\hline & King City & 85.1 & 94.0 & & \\
\hline & Tota1 & 1098.7 & 884.4 & & -20 \\
\hline \multirow{6}{*}{$\begin{array}{l}\text { South } \\
\text { Coastal }\end{array}$} & LADWP & 191.5 & 186.7 & 3 & \\
\hline & LADWP & 199.9 & 192.9 & 4 & " \\
\hline & E. LA & 520.7 & 501.7 & 4 & \\
\hline & Hermosa/Redonc & ado 380.6 & 343.6 & 4 & \\
\hline & Palos Verdes & 403.2 & 430.9 & 4 & \\
\hline & Total & 1695.9 & 1655.8 & & -2 \\
\hline \multirow{6}{*}{$\begin{array}{c}\text { Sacramento } \\
\text { Basin }\end{array}$} & Sacramento & 6707.0 & 5365.0 & 4 & \\
\hline & Willows & 118.1 & 108.7 & 4 & \\
\hline & Chico & 369.6 & 379.8 & 4 & \\
\hline & Marysville & 65.2 & 61.7 & 4 & \\
\hline & Oroville & 74.9 & 80.2 & 4 & \\
\hline & Tota1 & 7334.8 & 5995.4 & & -18 \\
\hline
\end{tabular}


TABLE 15 (continued)

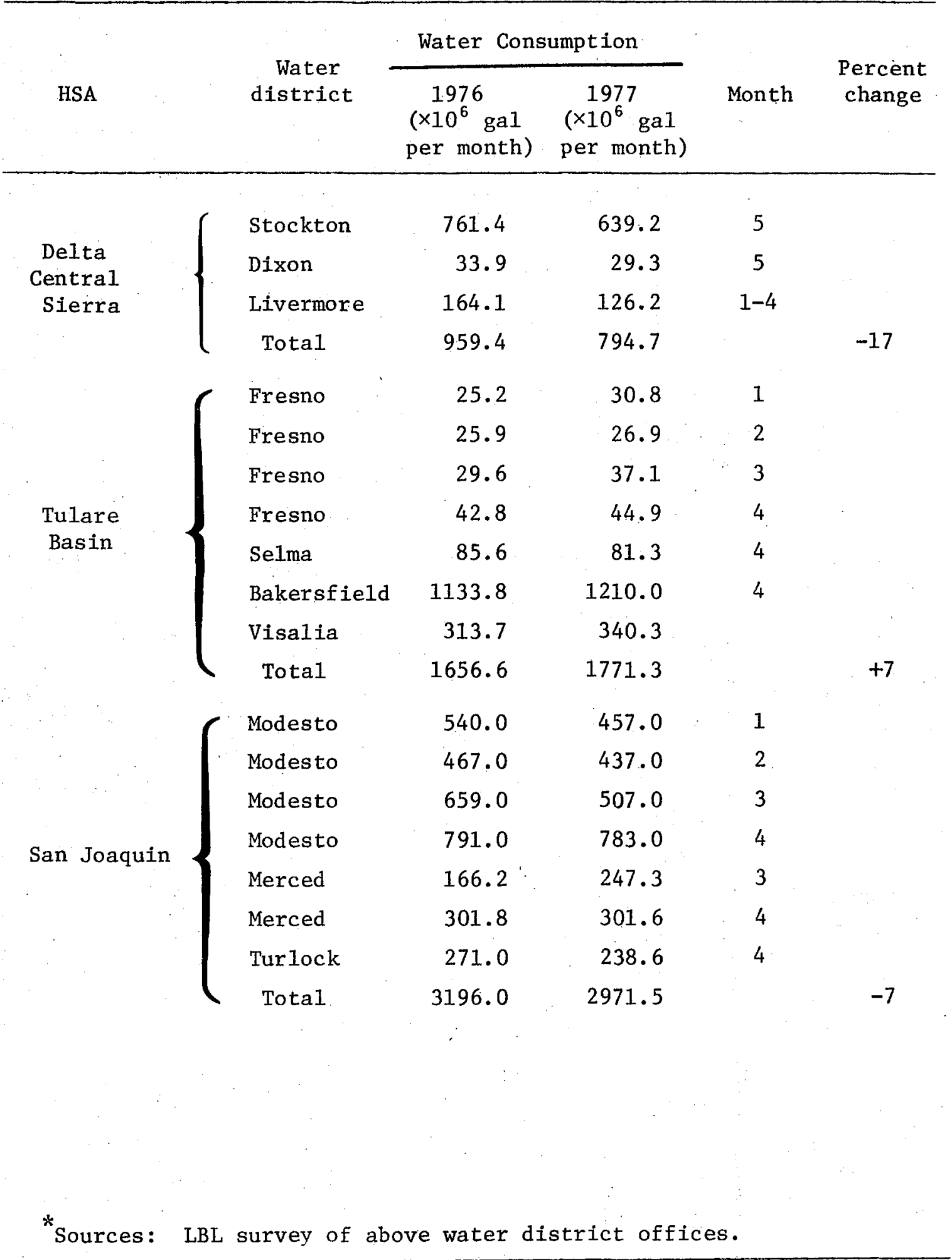


BIBLIOGRAPHY

General

[1] Association of California Water Agencies. California Water Resources Development: Water in California and Major Water Storage and Conveyance Facilities (Map). Sacramento, CA: Association of California Water Agencies, 1975.

[2] Berman, S.M., et a1. Electrical Energy Consumption in California Data Collection and Analysis, UCID-3847. Berkeley, CA: Lawrence Berkeley, Laboratory, July 1976.

[3] Copley International Corporation. The Market Structure of the Southern California Water Industry. Prepared for the Office of Water Resources Research, U.S. Department of the Interior. LaJo11a, CA: Copley International Corporation, June 1974.

[4] Department of Finance, State of California. Population Projections for California Counties 1975-2020, Alternative Series D-100, E-0, D-150, C-150. Report 74 P-2. Sacramento, CA: Department of Finance, 1974.

[5] Department of Water Resources, State of California, Bulletin 132-75: The California State Water Project. Sacramento, CA: DWR, 1975.

[6] Department of Water Resources, State of California. Bulletin 160-74: The California Water Plan, Outlook in 1974. Sacramento, CA: DWR, 1974 .

[7] Department of Water Resources, State of California. Bulletin 166-2: Urban Water Use in California. Sacramento, CA: DWR, 1975 . 
[8]. Department of Water Resources, State of California. Bulletin 198: Water Conservation in California. Sacramento, CA: DWR, 1976.

[9] Department of Water Resources, State of California. The California Drought, 1977: An Update. Sacramento, CA: DWR, February 15, 1977.

[10] East Bay Municipal Utility District. Water Production System (Map). Oakland, CA: November 1975.

[11] Hagen, Robert M., and Roberts Edwin B. Energy Conservation: Minimizing Energy Use in Water and Salt Management. Unpublished conference paper. Davis, CA: University of California.

[12] Hagan, Robert M., and Roberts, Edwin B. Energy Requirements for Wastewater Treatment and Reuse. Paper presented at the CWPCA Annual Conference, April 16, 1976.

[13] Hagan, Robert M., and Roberts, Edwin B. Energy Requirements for Wastewater Treatment. Water and Sewage Works, December 1976.

[14] Hagan, Robert M., and Roberts, Edwin B. Energy Requirements in Water Supply, Use and Conservation. Water and Sewage Works, November 1976.

[15] Hagan, Robert M., and Roberts, Edwin B. Energy Requirements of Alternatives in Water Supply and Wastewater Treatment. National Water Supp1y Improvement Journa1, January 1977, in press.

[16] Knutson, G., Curley, R., Roberts, E., Hagan, R., and Cervinka, V. Pumping Energy Requirements for Irrigation in California, Special Pub1ication 3125. Davis, CA: University of California, Division of Agricultural Sciences, March 1977. 
[17] Lawrence Berkeley Laboratory. LBL 6356. Effects of the Drought on California Electricity Supply and Demand. Sathaye, Benenson, Greene, Kahn, Krieg, Lasater, Ritschard,' Ruderman, Sextro, Siri, Vincent. June 1977.

[18] Los Angeles Times. "Who'11 Get the Water? California and the U.S. at Odds on Distribution." Series of Articles. Los Angeles, CA: Los Angeles Times, undated. Map by Don Clement.

[19] Moberg, L.E. Memorandum Report, Population Alternatives 19722020. Sacramento, CA: Department of Water Resources. January 2,1975 .

[20] Roberts, Edwin B., and Hagan, Robert M. Energy Requirements of Alternatives in Water Supply, Use, and Conservation: A Preliminary Report. Contribution No. 155, California Water Resources Center. Davis, CA: California Water Resources Center, December 1975.

[21] San Francisco Department of Public Works, Hetchy Water Supply of the City and County of San Francisco, California--General Map and Profile. San Francisco, CA: Department of Pub1ic Works, January 1925.

[22] State of California. California Statistical Abstract, 1975. Sacramento, CA: State of California Publications Office, 1975.

[23] U.S. Bureau of Reclamation. Annual Report of the Centra1 Valley Project, 1973. Washington, DC: GPO 1973.

[24] U.S. Bureau of Reclamation. Central Valley Operations: Report of Operations. Sacramento, CA: Central Valley Operations Coordination Office, December 1976. 
Residential Water Use

[25] Baker, Larry K. The Relationship Between Water and Energy Use and Conservation. Paper presented at 1976 Summer Workshop of Energy Extension Service, UC Berkeley, 19-24 July, 1976.

Berkeley, CA: Lawrence Berkeley Laboratory, May 1977.

[26] Baker, Larry K., Bailey, Harold E., and Sierka, Raymond A. Household Water Conservation Effects on Water, Energy, and Wastewater Management. Paper presented at the Second Annual Conference on Complete Water Reuse, Palmer House, Chicago, IL, 4-8 May 1975.

[27] Chemical Rubber Company. Handbook of Chemistry and Physics.

[28] Clear, Robert. Technical Aspects of Energy Conservation in Residential Hot Water Heaters. Berkeley, CA: Lawrence Berkeley Laboratory, unpublished report.

[29] Field Institute. The California Po11, Report \# 77-001, Release \# 935, March, 1977.

[30] Institute for Research on Land and Water Resources, Pennsylvania State University. Proceedings, Conference on Water Conservation and Sewage Flow Reduction and Water-Saving Devices. Information Report Number 74. University Park, PA: Pennsylvania State University, IRLWR, July 1975.

[31] Marin Municipal Water District, Water Supply Task Force Information Sheet. Marin, CA. MMWD, July 16, 1976. 
[32] Milne, Murray. Residential Water Conservation. California Water Resources Center Report No. 35. Davis, CA: CWRC, March 1976.

[33] Mutch, James J. Residential Water Heating, Fue1 Conservation, Economics and Public Policy. The Rand Corporation, R-1498. Santa Monica, CA: The Rand Corporation.

[34] Quinn, Richard S., Jr. The Effects of Increased Capita1 Expenditure as a Method of Reducing Electricity Demand for Hot Water Generation in New Homes, M.S. Thesis. Knoxville, Tennessee: University of Tennessee, August 1972.

[35] Sharpe, William. Water Conservation and Wasteflow Reduction in the Home. University Park, PA: Pennsylvania State University Institute for Research on Land and Water Resources, 1974.

Industria1 Water Use

[36] California State Water Resources Control Board. Policy and Action Plan for Water Reclamation in California. Sacramento, CA: Water Resources Contro1 Board, January 1977.

[37] Canton, Trancuilo. Blow-Down and Make-Up Water Conservation. Lawrence Berkeley Laboratory Engineering Note, March 3, 1977. Berkeley, CA: Lawrence Berkeley Laboratory 1977.

[38] Crook, James. Reliability of Wastewater Reclamation Facilities. State of California: Water Sanitation Section, Department of Health, 1976. 
[39] Department of Water Resources, State of California. Bulletin 68-73: Inventory of Waste Water Production and Waste Water Reclamation in California, 1973. Sacramento, CA DWR, 1975.

[40] Department of Water Resources, State of California. Bulletin 124-2: Water Use by Manufacturing Industries in California, 1970. Sacramento, CA: DWR, March 1977.

[41] Employment Development Department, State of California. Wage and Salary Workers in Nonagricultural Establishments, by Industry: California. Part A: 1966-1975. Sacramento, CA: Employment Development Department, 1976.

[42] Okun, Daniel A. Alternatives in Water Supply. Journal of the American Water Works Association, Vol. 61, No. 5, May 1969.

[43] Thompson, Sidney J. Techniques for Reducing Refinery Wastes. Oi1 and Gas Journa1, October 5, 1970, pp. 93-98.

[44] U.S. Department of Commerce, Bureau of the Census. 1972 Census of Manufactures: Water Use in Manufacturing. Specia1 Report Series. MC72 (SR)-4. Washington, DC: GPO, 1976.

[45] U.S. Enviromental Protection Agency. Development Document for Proposed Effluent Limitations Guidelines and New Source Performance Standards for ... (industry)... Point Source Category. 440 Series. Washington, DC: EPA, January 1974; where (industry) is: 


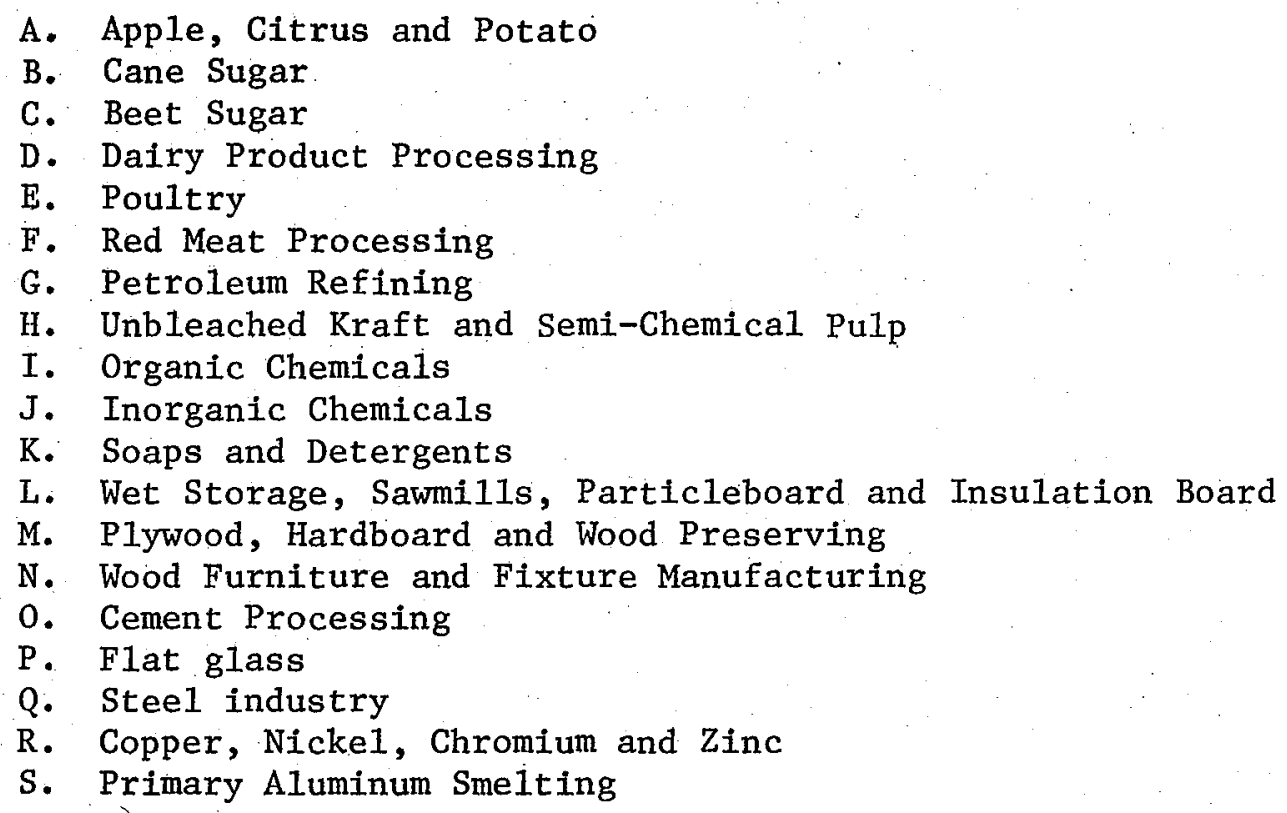

[46] U.S. Enviromental Protection Agency. A Primer on Wastewater Treatment. Washington, DC: EPA, July 1976.

[47] U.S. National Commission on Water Quality. Report. Washington, DC: GPO, April 1976.

\section{Personal Communications}

[48] California Water Service Company. Mr. Lorenzen (5/23/77), Deliveries, water conservation.

[49] Canners League of California. James Bell (3/3/77). Water consumption, water conservation.

[50] Chevron U.S.A., Richmond, California. Mr. Henderson (3/3/77) and $\mathrm{Mr}$. Fuerso $(4 / 15 / 77)$. Water consumption, water conservation. 
[51] City of Sacramento. Daniel Stockton. Water conservation.

[52] Contra Costa County Water District. Wally Allen. Delivery energy for Contra Costa Canal.

[53] Department of Health, State of California. Dr. David Spath. Wastewater treatment facilities in California. Berkeley, CA.

[54] Department of Sanitary Engineering, UC Berkeley, William J. Oswald. Wastewater treatment facilities in California.

[55] Department of Water Resources, State of California. Frank Lombard $(5 / 77)$. Present water conservation and consumption. Sacramento, CA.

[56] Department of Water Resources, State of California. L.E. Moberg. Population for HSAs. Sacramento, CA.

[57] Department of Water Resources, State of California. Jerry Vayder and Richard Wagner. Industrial cooling water, brackish water.

[58] Dow Chemica1, Pittsburg, California. Thomas Lange (3/3/77), (3/ $21 / 77)$. Water consumption, water conservation.

[59] East Bay Municipal Utility District. Helen Burke, (8/2/77). Proposed water supply projects.

[60] East Bay Municipal Utility District. Keith Carnes and Paul Fletcher. Deliveries, distribution energy. 
[61] East Bay Municipal Utility District. Pau1 Fletcher. Water deliveries, energy for distribution.

[62] Employment Development Department, State of California. Ben Traverso (5/16/77). Seasonally adjusted employment figures by industry for 1977. Sacramento, CA.

[63] Environmental Defense fund. Thomas Graff, (8/2/77). Proposed water supply projects.

[64] Fibreboard Corporation. Edward Oetkin, (7/25/77). Water savings at Fibreboard Corporation (reported at the Drought Conference on Industry Water Allocation and Conservation, Sheraton Inn-Airport, Concord, CA).

[65] Fresno Water Department. Manuel Staffero (5/23/77). Deliveries, water conservation. Fresno, CA.

[66] Hetch Hetchy Water and Power Department. James Leonard, (8/2/77). Proposed water supply projects.

[67] Hetch Hetchy Water and Power Department. Mr. Moore, (8/2/77), Proposed water supply project.

[68] Hetch Hetchy Water and Power Department. Harry Tracey. Delivery energy costs.

[69] Hewlett-Packard Co. Glen Affleck, (7/25/77). Water Conservation at Hewlett Packard (reported at the Drought Conference on Industry Water Allocation and Conservation, Sheraton Inn-Airport, Concord, CA). 
[70] Kaiser Stee1 Corporation. E.L. Relph (4/12/77), (4/13/67). Water consumption and conservation.

[71] Lawrence Berkeley Laboratory, (Plant Engineering Department). Y. Kim, (7/25/77). Water Conservation at Lawrence Berkeley Laboratory.

[72] Los Angeles Department of Water and Power. Dane Hooper. Distribution energy costs, delivery energy costs.

[73] Los Angeles Department of Water and Power. L. Lund (3/3/77), $(4 / 29 / 77)$. Industrial water conservation.

[74] Los Angeles Department of Water and Power. Robert Pagan, $(8 / 3 / 77)$. Overdraft in the Owens Valley.

[75] Marin Municipal Water District. Water Conservation Information office. Water savings from flow control restrictors.

[76] Metropolitan Water District. Public Relations Department. Energy requirements for water distribution.

[77] Metropolitan. Water District. Ted Voyles. Water conservation, Los Angeles, CA.

[78] Modesto Water Department. Richard Rodriguez (5/23/77): Deliveries, water conservation.

[79] Nationa1 Canners Association. Allen Katsuyama, (7/25/77). Water savings in the canning industry (reported at the Drought Conference on Industry Water allocation and Conservation, Sheraton Inn-Airport, Concord, CA). 


$$
-77-
$$

[80] Sacramento City Water. Harry Barrons (5/5/77). Distribution energy.

[81] San Diego Water Department. (5/23/77). Water conservation.

[82] San Diego Water Department. Gary Hogue. Distribution energy requirements.

[83] San Francisco Water Department. Mr. Chang. Water use, energy, for water distribution.

[84] San Francisco Water Department. Mr. Alfred Hamilton, energy consumption.

[85] San Francisco Water Department. Mr. Vasconcellos (5/23/77). Water conservation.

[86] Santa Barbara Water Works. William Hill (5/25/77). Water conservation and deliveries.

[87] Santa Cruz Water Department. Tracey Bliss (5/25/77). Water conservation.

[88] Standard Oil Refinery. James Gilliland, (7/25/77). Water savings at Standard Oil (reported at the Drought Conference on Industry Water Allocation and Conservation, Sheraton Inn-Airport, Concord, CA).

[89] Stockton City Water Division (5/25/77). Deliveries and water conservation. 


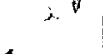

$7^{\circ}$ 